\title{
Transport properties and fouling issues of membranes utilized for the concentration of dairy products by air-gap membrane distillation and microfiltration
}

\author{
Joanna Kujawa ${ }^{1} \cdot$ Ewelina Chrzanowska $^{1} \cdot$ Wojciech Kujawski ${ }^{1}$
}

Received: 14 August 2018 / Accepted: 10 October 2018 / Published online: 15 October 2018

(c) The Author(s) 2018

\begin{abstract}
The work contains results related to the application of membrane separation processes (i.e., membrane distillation and microfiltration) in dairy products processing. The performance of titania ceramic membranes (pristine as well as hydrophobized) was studied in the microfiltration process of whey and lactose solutions. On the other hand, polymeric porous hydrophobic membranes, (polypropylene-PP and polytetrafluoroethylene-PTFE) were tested in the air-gap membrane distillation (AGMD) process in contact with whey and lactose solutions. The extended material and physiochemical characterization (including fouling issues) of membrane materials before and after the separation process was performed. Transport of lactose solution across the membranes was characterized by higher effectiveness comparing with whey solution. Lactose played an important role and reduced the interactions with membrane material. Lactose solution possessed lower adhesion ability than whey what influenced the fouling and reduction of permeate flux. Membrane distillation was found to be a process that generates high-quality water with retention $>99 \%$ while simultaneously concentrating whey or lactose solutions. Microfiltration process was characterized by a rejection of lactose in the range of 80-90\% for pristine ceramic membrane and hydrophobized one, respectively. The tendency to fouling in the case of AGMD process was associated with the higher contribution of polar part (29\%) of the surface free energy SFE for PTFE membrane. The lowest value of normalized flux decline was observed for PP membrane, and that was correlated with the smallest contribution of polar interaction in SFE, the lowest value of roughness (RSM), contact angle (CA), and contact angle hysteresis (HCA), determined for the membrane after its utilization in the separation process.
\end{abstract}

Keywords Lactose $\cdot$ Whey $\cdot$ Microfiltration · Air-gap membrane distillation $\cdot$ Hydrofobization of ceramics $\cdot$ Fouling phenomena

\begin{tabular}{|c|c|c|c|}
\hline \multicolumn{2}{|c|}{ Abbreviations } & \multirow{2}{*}{$\begin{array}{l}\text { MD } \\
\text { MF }\end{array}$} & \multirow{2}{*}{$\begin{array}{l}\text { Membrane distillation } \\
\text { Microfiltration }\end{array}$} \\
\hline \multicolumn{2}{|r|}{ Octyltriethoxysilane } & & \\
\hline \multirow{2}{*}{$\begin{array}{l}\mathrm{CA} \\
\mathrm{C}_{\mathrm{f}}\end{array}$} & Contact angle [deg] & MWCO & Molecular weight cut off [Da] \\
\hline & Lactose concentration in the feed $\left[{ }^{\circ} \mathrm{Brix}\right]$ & NF & Nanofiltration \\
\hline \multirow{2}{*}{$\begin{array}{l}\mathrm{C}_{\mathrm{p}} \\
\mathrm{HCA}\end{array}$} & Lactose concentration in the permeate $\left[{ }^{\circ} \mathrm{Brix}\right]$ & FRR & Flux recovery ratio \\
\hline & Contact angle hysteresis [deg] & NTU & Nephelometric turbidity units \\
\hline FC6 & $1 \mathrm{H}, 1 \mathrm{H}, 2 \mathrm{H}, 2 \mathrm{H}-\mathrm{Perfluorooctyltriethoxysilane}$ & $\mathrm{NTU}_{\mathrm{f}}$ & Turbidity of feed [NTU] \\
\hline \multirow{2}{*}{$\begin{array}{l}\mathrm{FD}_{\mathrm{n}} \\
\mathrm{IRDR}\end{array}$} & Normalized flux decline & $\mathrm{NTU}_{\mathrm{p}}$ & Turbidity of permeate [NTU] \\
\hline & Irreversible flux decline ratio & PP & Polypropylene \\
\hline$J_{0}$ & Initial permeate flux $\left(\mathrm{kg} \mathrm{m}^{-2} \mathrm{~h}^{-1}\right)$ & PTFE & Polytetrafluoroethylene \\
\hline \multirow[t]{2}{*}{$J_{\mathrm{f}}$} & \multirow[t]{3}{*}{ Final permeate flux $\left(\mathrm{kg} \mathrm{m}^{-2} \mathrm{~h}^{-1}\right)$} & RDR & Reversible flux decline ratio \\
\hline & & RMS & Root square mean $[\mathrm{nm}]$ \\
\hline & & $\mathrm{R}_{\mathrm{L}}$ & Lactose rejection $(\%)$ \\
\hline \multirow{2}{*}{$\begin{aligned} & \triangle \mathrm{W}_{\mathrm{c}} \\
& \mathrm{ku}\end{aligned}$} & \multirow{2}{*}{$\begin{array}{l}\text { Wojciech Kujawski } \\
\text { kujawski@chem.umk.pl }\end{array}$} & $\mathrm{S}$ & Spreading pressure $\left(\mathrm{mN} \mathrm{m}^{-1}\right)$ \\
\hline & & SFE & Surface free energy $\left(\mathrm{mN} \mathrm{m}^{-1}\right)$ \\
\hline & \multirow{2}{*}{$\begin{array}{l}\text { Nicolaus Copernicus University in Toruń, Faculty } \\
\text { of Chemistry, } 7 \text { Gagarina St., } 87-100 \text { Torun, Poland }\end{array}$} & $\mathrm{TC}$ & Turbidity coefficient \\
\hline & & UF & Ultrafiltration \\
\hline
\end{tabular}




$\begin{array}{ll}\sigma_{\mathrm{L}} & \text { Liquid surface tensions }\left(\mathrm{mN} \mathrm{m}^{-1}\right) \\ \sigma_{\mathrm{S}} & \text { Solid surface tensions }\left(\mathrm{mN} \mathrm{m}^{-1}\right) \\ \sigma_{\mathrm{SL}} & \text { Interfacial surface tensions }\left(\mathrm{mN} \mathrm{m}^{-1}\right)\end{array}$

\section{Introduction}

The separation and purification of dairy products can be accomplished with high effectiveness by implementing pressure-driven membrane technologies. However, there is a necessity to apply high-pressure differences across the membrane (e.g., ultrafiltration-UF or nanofiltration-NF) (Al-Gharabli et al. 2018; Chenchaiah et al. 2013; Christensen et al. 2006; Qtaishat and Banat 2013; Zaragoza et al. 2014), which generates high cost of the process, usually smaller in the case of microfiltration (MF) process. One of the solutions is to employ a membrane distillation (MD) process (Al-Gharabli et al. 2018; Chenchaiah et al. 2013) instead of ultra- or microfiltration. MD is a thermally driven membrane process performing at low feed temperatures comparing to the conventional distillation processes permitting to use the waste heat from industrial systems or even solar energy (Qtaishat and Banat 2013; Zaragoza et al. 2014). Furthermore, an important advantage of MD is a mild processing of heat-sensitive ingredients comparing with the evaporative technologies (Christensen et al. 2006). A significant issue to successful MD operation is the hydrophobic and porous membrane. The hydrophobic character of the membrane protects the membrane from wetting during the separation process. The dairy streams possess complex chemistries of components (e.g., fats, various proteins, and minerals) which are recognized as potential membrane foulants. Fouling is a major drawback for effective membrane operation during the course of membrane process as it reduces flux across the membrane (James et al. 2003). Furthermore, MD membrane fouling also escalates the risk of membrane wetting by compounds migrating into the membrane pores and plugging of the flow channels.

Fouling can impact membrane performance at different ways, e.g., by flux reduction during the process related to the increase of temperature polarization, and thermal resistance, decrease of active membrane area as well as increased tortuosity for mass transfer. This fact is associated with the specific interactions between various solutes present in feed solution and membrane material as well as with the interactions among other solutes in the solution including absorbed solutes (Hausmann et al. 2013b; James et al. 2003; Rezaei et al. 2014). Due to the high complexity of feed stream in the case of dairy product separation, it should be remembred that each component of feed stream will interact in a different way with the material of the membrane (Hausmann et al. 2011, b). Considering membrane material polymeric as well as ceramic samples needs to be taken into account. Chiu (2011) discussed the advantages of the utilization of ceramic membrane to microfiltration process of whey. The author presented in detail membrane characterization in terms of the relation between the ceramic membrane and whey ingredients. An important impact of such interactions and time/aging on the electrokinetic characterization was pointed out. The most meaningful was an influence on zeta potential and fluxes at the alkaline $\mathrm{pH}$ compared to the acidic $\mathrm{pH}$ as well as the $\mathrm{pH}$ corresponding to the isoelectric point. Chiu (2011) has shown that highest level of removed total organic carbon has been noticed at alkaline $\mathrm{pH}$. In spite of the point that the surface charge depends only on the $\mathrm{pH}$, the differences in the alumina material may convince diverse strengths of electrostatic or hydrophobic interactions between particles and membrane material (Chiu 2011). Furthermore, Kulozik et al. (2015; Steinhauer et al. 2015) discussed the ultra-microfiltration of whey with application of various ceramic (for $\mathrm{UF}^{\mathrm{A}} \mathrm{I}_{2} \mathrm{O}_{3} / \mathrm{TiO}_{2}-20 \mathrm{kD}$

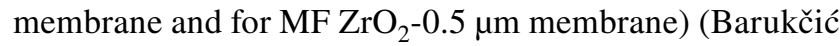
et al. 2015) and polymeric membranes (for UF polyethersulphone PES $30 \mathrm{kD}$ and for MF PES $0.1 \mu \mathrm{m}$ membrane) (Steinhauer et al. 2015). In the following work (Barukčić et al. 2015), MF process was used as a pre-treatment step having an important impact on the UF process by enhancing transport properties and reducing fouling, despite the fact that microbial reduction was practically equal to pasteurization. The zeta potential and protein conformation will impact the aforementioned interactions between membrane and feed (Hausmann et al. 2013b; Rezaei et al. 2014). It is also estimated that the chemistry of the feed components will influence the fouling mechanism during the separation process of dairy products. The problem of membrane fouling by dairy products has been studied by various research groups in the case of micro and ultrafiltration (Barclay et al. 2018; Chen et al. 2018; Jukkola et al. 2018; Nath et al. 2018; Soodam and Guinee 2018) as well as membrane distillation (Gryta 2008; Hausmann et al. 2011, 2013a). In the case of MF/UF processes, the application of membranes possessing lower hydrophobicity (water contact angle of $60^{\circ}-70^{\circ}$ ) was suggested (Barclay et al. 2018; Chen et al. 2018; Jukkola et al. 2018; Soodam and Guinee 2018), whereas, in the membrane distillation utilization of hydrophobic porous membranes, e.g., polypropylene (PP) and polytetrafluoroethylene (PTFE) is proposed (Gryta 2008; Hausmann et al. 2013a). Hausmann et al. (2011, 2013a, b, 2014) investigated the effect of different combinations of the whey and milk components on MD performance. Hausmann's research group (Hausmann et al. 2011, 2013a, b, 2014) studied the mechanism of membrane fouling during MD process of dairy products, e.g., skim milk, whey, and lactose solutions. 
Authors presented the impact of each whey component on the separation process (Hausmann et al. 2013a, b, 2014). Comparing to proteins, fat appeared to create stronger interactions leading to fouling. Whey solution showed fouling related to time, while skim milk solution fouling was more related to dry-matter concentration. Moreover, it was found that linear velocity influences the performance in the course of skim milk processing but not during whey processing. It was shown that the concentration of skim milk and whey by membrane distillation was characterized by high rejection coefficient ( $>99 \%$ ) of all dairy components (Hausmann et al. 2011, 2014). Gryta et al. (2008) paid attention to the problem of fouling formation, which caused a significant decrease of fluxes in membrane processes. Christensen et al. (Christensen et al. 2006) focused on the increase in dry-matter of whey protein concentrate up to $34 \%$ total solids, implementing the MD process with polypropylene membrane tubes. Moejes et al. (Moejes and van Boxtel 2017) presented the application of MD for skim milk concentration by membrane distillation. Erdem and co-workers (Erdem et al. 2006) elaborated the application of ceramic composite membranes (alumina-zirconia) for separation of whey components. Membranes possessed good protein lactose separation properties with a relatively high protein content $\sim 80 \%$ and with relatively low lactose retention $\sim 7 \%$ (Erdem et al. 2006).

The aim of the present work (Fig. 1) was to assess the membrane performance of ceramic membranes (pristinehydrophilic and hydrophobized) in microfiltration process and polymeric ones (polypropylene-PP and polytetrafluoroethylene-PTFE) in air-gap membrane distillationAGMD in the concentration of lactose and whey solutions. Separation processes were implemented for the concentration of lactose and whey. The novelty of the work was

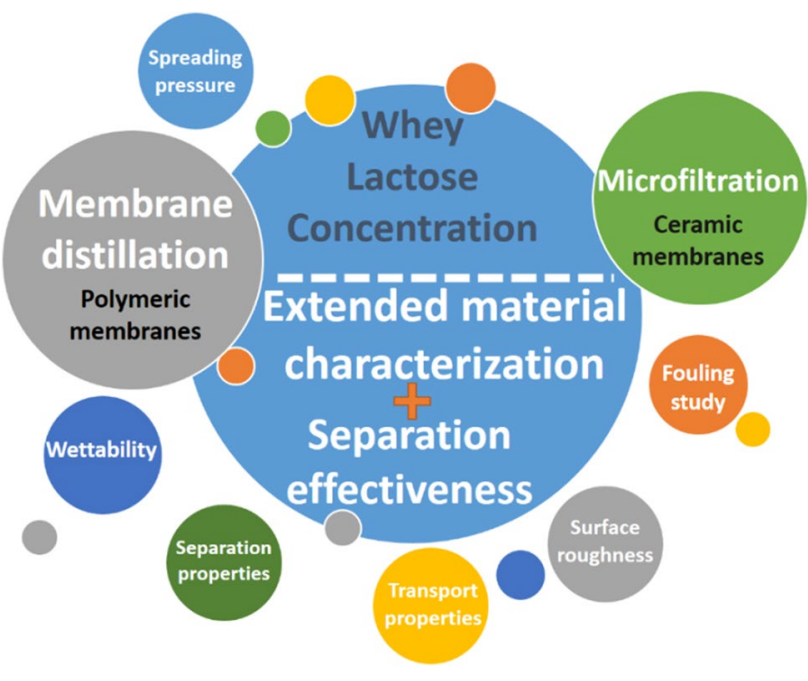

Fig. 1 The interdisciplinary idea of the research to choose different processes and membranes leading to establish the broad spectrum of data and to correlate membrane performance with extended material characterization (contact angle - CA and its hysteresis- HCA, roughnessRMS, surface free energy-SFE, spreading pressure-S) prior and after each membrane utilization which was the cognitive goal of the research. The presented work aims also to find out how the membrane material (e.g., morphology and chemistry of the membrane) affects the dairy product separation.

\section{Experimental part}

\section{Materials and chemicals}

Ceramic ultrafiltration $(5 \mathrm{kD})$ and microfiltration $(300 \mathrm{kD})$ tubular titania $\left(\mathrm{TiO}_{2}\right)$ membranes (inert/outher dimension 7/10 mm) were purchased from TAMI Industry, France. The commercially available hydrophobic porous membranes from polypropylene (PP) and polytetrafluoroethylene (PTFE) were used in the experiments. Polypropylene samples with a nominal pore size of $0.10 \mu \mathrm{m}$ (labeled as PP10) were purchased from Celgard, USA. Another type of PTFE membranes with pores of $0.20 \mu \mathrm{m}$ (labeled as PTFE20) and $0.45 \mu \mathrm{m}$ (labeled as PTFE45) were supplied by Sartorius Stedim, Germany.

$1 \mathrm{H}, 1 \mathrm{H}, 2 \mathrm{H}, 2 \mathrm{H}$-Perfluorooctyltriethoxysilane (named as FC6) and octyltriethoxysilane (named as C6) were purchased from Abcr chemicals (Germany). Acetone, ethanol, chloroform (stabilized by $1 \%$ ethanol), and lactose were provided by Avantor Performance Materials (Poland) and used without further purification. Powdered whey containing $70 \mathrm{wt} \%$ of lactose was kindly provided by a local creamery (Rypin, Poland).

\section{Modification process of the ceramic membranes}

Modifying agent solutions of $1 \mathrm{H}, 1 \mathrm{H}, 2 \mathrm{H}, 2 \mathrm{H}-$ Perfluorooctyltriethoxysilane and octyltriethoxysilane with the concentration of $0.05 \mathrm{M}$ were prepared in chloroform. Membranes were kept in the chosen grafting solutions for $5 \mathrm{~h}$ at room temperature. The modification process, as well as preparation steps, was done under ambient argon atmosphere. The detailed experimental protocol is presented elsewhere (Kujawa et al. 2017; Kujawa and Kujawski 2016). Microfiltration measurements were chosen as a separation process for ceramic membranes.

\section{Microfiltration experiments}

The microfiltration experiments were performed using the setup provided by Intermasz Membrane Filtration Ltd 

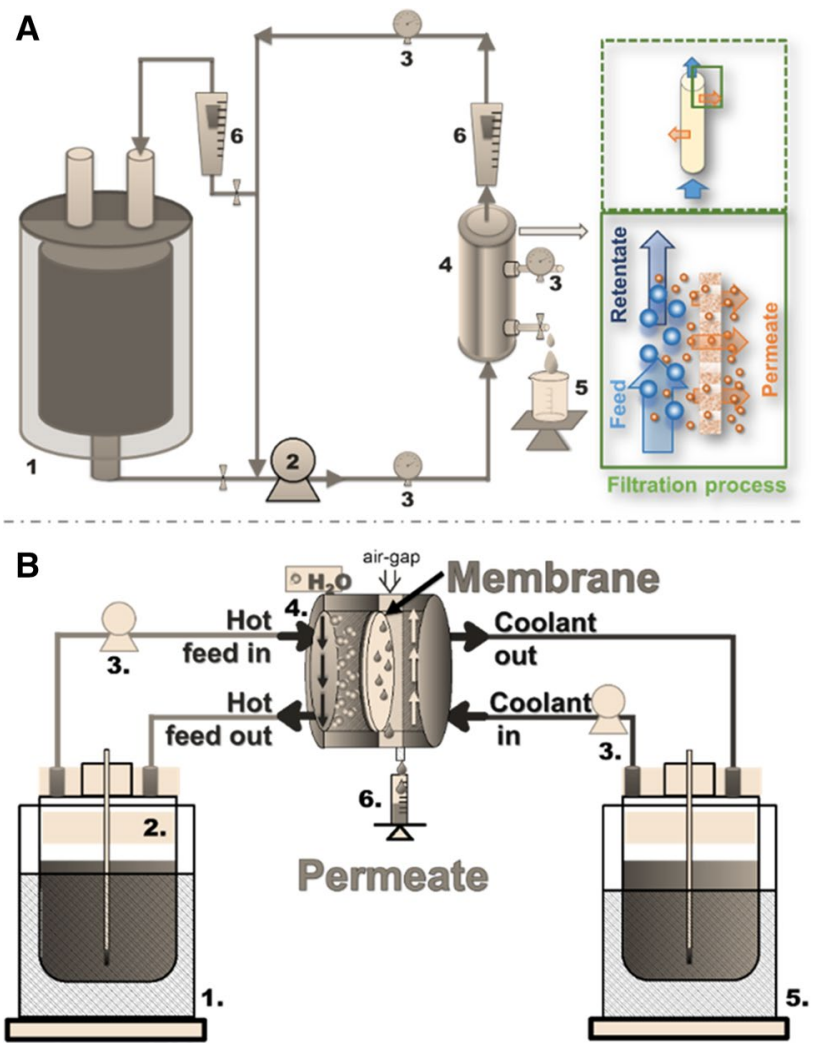

Fig. 2 a Filtration experimental setup: 1-thermostated feed tank, 2-circulating pump, 3-manometer, 4-membrane module, 5beaker and balance, 6-rotameter. b Air-gap membrane distillation experimental rig. 1-thermostat, 2-feed tank, 3-pumps, 4-membrane distillation module with $4 \mathrm{~mm}$ air-gap, 5-cryostat, 6-cylinder and balance for permeate collection

(Września, Poland) (Fig. 2a) in the batch mode, described in detail elsewhere (Knozowska et al. 2017).

Two types of the ceramic membranes were used during the experiment, $\mathrm{TiO}_{2}$ tubular ceramic membrane with a molecular weight cut off (MWCO) equal to 5 and $300 \mathrm{kD}$. Membranes possessed an active surface area of $25.2 \mathrm{~cm}^{2}$. The feed solution was transported from the thermostated tank (3 L volume) to the membrane module. Subsequently, the retentate was recirculated back to the feed tank (Fig. 2a). The transport properties of the investigated membranes were assessed by a gravimetric method using an analytical electronic balance. Prior to the filtration process of whey solution, the experiment with pure water as a feed was performed, allowing to determine the reference fluxes for all examined membranes. In the next step, various concentrations (5, 10 and $12 \mathrm{wt} \%$ ) of lactose aqueous solutions and whey were used. The mentioned solutions were prepared based on the powdered whey containing $70 \mathrm{wt} \%$ of lactose (in the case of whey) and pure lactose. The selected concentrations were related to the level of lactose in raw milk as well as in the condensed milk (Huppertz 2013; Pruksasri
2015). During the filtration experiments, the applied temperature and transmembrane pressure conditions were equal to $30{ }^{\circ} \mathrm{C}$ and 2 bar, accordingly. In the course of the experiments, a constant rate of feed solution equal to $75 \mathrm{~L} \mathrm{~h}^{-1}$ was maintained over the membrane module. The filtration effectiveness was assessed by determining the turbidity using Turbidimeter TN-100 (Eurotech Instrument, Singapore). The turbidity coefficient (TC) of the filtration process was calculated based on the Eq. (1), where $\mathrm{NTU}_{\mathrm{f}}$ is the feed turbidity and $\mathrm{NTU}_{\mathrm{p}}$ denotes the permeate turbidity.

$\mathrm{TC}=\left(1-\left(\frac{\mathrm{NTU}_{p}}{\mathrm{NTU}_{f}}\right)\right) \cdot 100 \%$

The refractive index of a sample comparative to the refractive index of water was measured with an Abbe refractometer (PZO-RL1, Warsaw, Poland). The refractometer was blanked with distilled water before each measurement. The analyses were done at room temperature. The values of the determined refractive index were converted in lactose concentrations in ${ }^{\circ}$ Brix (Caprita et al. 2014). Lactose rejection $\left(R_{\mathrm{L}}\right)$ coefficient was determined based on the refractometric analysis (Caprita et al. 2014); $R_{\mathrm{L}}$ (Eq. 2) were taken into account during separation features assessment:

$R_{\mathrm{L}}=\left(1-\left(\frac{C_{\mathrm{p}}}{C_{\mathrm{f}}}\right)\right) \cdot 100 \%$,

where $C_{\mathrm{p}}$ is lactose concentration in the permeate and $C_{\mathrm{f}}$ lactose concentration in the feed.

\section{Air-gap membrane distillation measurements}

AGMD process (Fig. 2b) was realized with pure water as well as with solutions of lactose and whey as feed solutions. The flux of pure water for each membrane sample was determined to define the reference flux through membranes. Measurements were accomplished at $50 \pm 2{ }^{\circ} \mathrm{C}$ of feed temperature and $15 \pm 2{ }^{\circ} \mathrm{C}$ for permeate that was related to the driving force of $106 \pm 0.68 \mathrm{mbar}$. Each experiment was conducted at least for $10 \mathrm{~h}$. The detailed description of the process is presented elsewhere (Kujawska et al. 2016).

\section{Membrane characterization}

Membrane morphology was determined by SEM technique with Quanta 3D FEG (USA) apparatus. At the outset of imaging membranes, the samples were sputtered with a gold-palladium nanolayer $(10 \mathrm{~nm})$ to improve the conductivity of sample surfaces and subsequently to obtain data of much better quality.

Pore size and pore size distribution of polymeric membranes were determined using Coulter Porometer II apparatus 
(Coulter Electronics Ltd., UK) and employing modified bubble point method described in detail elsewhere (Hernández et al. 1996; Kujawski et al. 1989; Szczerbińska et al. 2017). Prior to the experiment membrane samples were wetted by a liquid with low surface tension (Porefil, $\sigma=16 \mathrm{mN} \mathrm{m}^{-1}$ ) to fill the membrane pores. Measurements were done 2-3 times for different samples of the same membrane batch. Roughness parameter (RMS-root mean squared roughness) was assessed using tip scanning mode and scanning sample area of $5 \mu \mathrm{m} \times 5 \mu \mathrm{m}$ applying AFM-atomic force microscopy (NanoScope MultiMode SPM System and NanoScope IIIa i Quadrex controller, Veeco, Digital Instrument, UK). The RMS values for examined membranes were established according to an integrated mathematical algorithm in NanoScope Analysis Software (1.40, Build R3Sr5.96909, 2013 Bruker Corporation).

Goniometric measurements were implemented for the determination of the contact angle (CA) values for water, glycerol, and diiodomethane. Moreover, the hysteresis of CA was determined. Based on the established CA data the surface free energy values were calculated according to the Owens, Wendt, Rabel, and Kaelble (OWRK) method (Law and Zhao 2016) (Eq. 3). Image J software (Image J, NIH-freeware version) was used for data interpretation of CA with an accuracy of $\pm 1^{\circ} .20-30$ individual measurements were conducted, and the average values are presented. All the above-mentioned parameters (i.e. morphology, CA, SFE, RMS) were determined prior and directly after the filtration process.

$\sigma_{\mathrm{SL}}=\sigma_{\mathrm{S}}+\sigma_{\mathrm{L}}-2\left(\sqrt{\sigma_{\mathrm{S}}^{\mathrm{D}} \cdot \sigma_{\mathrm{L}}^{\mathrm{D}}}+\sqrt{\sigma_{\mathrm{S}}^{\mathrm{P}} \cdot \sigma_{\mathrm{L}}^{\mathrm{P}}}\right)$,

where $\sigma_{\mathrm{S}}=\sigma_{\mathrm{SL}}+\sigma_{\mathrm{L}} \cdot \cos (\mathrm{CA}) . \sigma_{\mathrm{L}}$ is liquid surface tension, $\sigma_{\mathrm{SL}}$ is the interfacial tension between liquid and solid, and $\sigma_{\mathrm{S}}$ the surface free energy of the solid-SFE.

Moreover, spreading pressure (Eq. 4) was determined (Bikerman 1963; Good 1975). This parameter is defined by a difference of adhesion work $\left(W_{1,2}\right)$ between phases and cohesion work $\left(W_{1,1}\right)$ of the phase being under consideration (testing liquid) and possesses an important meaning in the evaluation of wetting.
$S=W_{1,2}-W_{1,1}$

$S=\sigma_{\mathrm{S}}-\sigma_{\mathrm{L}}-\sigma_{\mathrm{SL}}$

Compatibly, the spreading pressure $(S)$ can be expressed as the difference between surface tensions $\sigma_{\mathrm{S}}$ and $\sigma_{\mathrm{L}}$ and the interfacial tension $\sigma_{\mathrm{SL}}$ (Eq. 5). The determined value of the $S$ can be negative or positive (Bikerman 1963; Good 1975). In the case of a negative value, the wetting is not complete; however, for a positive $S$ value, the liquid penetration into the material is observed. The higher the value of a spreading coefficient between surface and liquid, the greater the thermodynamic work of adhesion in comparison to the cohesive energy of testing liquid, i.e., the high value of $S$ will cause reduction of cohesive and the rise of adhesion. As a result, the higher wetting will be observed.

\section{Results and discussion}

\section{Material properties of ceramic membranes}

All types of the ceramic membranes, pristine and functionalized ones, were characterized by various analytical techniques. Hydrophobicity level, AFM imaging, and calculations of surface free energy (SFE) were implemented. The determined parameters were established for the sample before and after their utilization in filtration process of lactose and whey solutions. Finally, the achieved parameters were compared and discussed. The obtained data are gathered in Table 1.

According to the data presented in Table 1, it can be seen that the modification process influences the physiochemistry of the surface of separation materials in a significant way. It was proved that pristine hydrophilic material became hydrophobic, possessing the $\mathrm{CA}$ above $135^{\circ}$. The higher value of the CA for FC6 sample was related to the presence of fluorine in the grafting molecules (Kujawa et al. 2017; Kujawa and Kujawski 2016). The grafting process caused also a reduction of contact angle hysteresis. Substantial reduction of surface free energy was associated with the formation of
Table 1 Physicochemical properties of applied ceramic membranes $\left(\mathrm{TiO}_{2}-300 \mathrm{kD}\right)$

\begin{tabular}{|c|c|c|c|c|c|c|}
\hline Membrane & CA (deg) & HCA (deg) & $\mathrm{S}\left(\mathrm{mN} \mathrm{m}^{-1}\right)$ & $\operatorname{SFE}\left(\mathrm{mN} \mathrm{m}^{-1}\right)$ & $\mathrm{SFE}^{\text {polar }}\left(\mathrm{mN} \mathrm{m}^{-1}\right)$ & RMS (nm) \\
\hline \multicolumn{7}{|c|}{ Membranes before filtration process } \\
\hline Pristine & $40 \pm 1$ & - & $-17.0 \pm 0.6$ & $167.6 \pm 0.7$ & $43.4 \pm 0.3$ & $62.0 \pm 2.1$ \\
\hline C6 & $135 \pm 1$ & $22 \pm 1$ & $-124.3 \pm 4.1$ & $24.8 \pm 0.4$ & $5.0 \pm 0.1$ & $23.2 \pm 1.2$ \\
\hline FC6 & $142 \pm 1$ & $19 \pm 1$ & $-130.2 \pm 4.3$ & $15.7 \pm 0.3$ & $0.8 \pm 0.01$ & $18.1 \pm 0.8$ \\
\hline \multicolumn{7}{|c|}{ Membranes after the filtration process } \\
\hline Pristine & $44 \pm 1$ & - & $-20.4 \pm 0.7$ & $163.8 \pm 0.8$ & $42.9 \pm 0.4$ & $74.4 \pm 2.8$ \\
\hline C6 & $130 \pm 1$ & $29 \pm 1$ & $-119.6 \pm 3.9$ & $32.1 \pm 0.5$ & $8.0 \pm 0.2$ & $28.6 \pm 2.1$ \\
\hline FC6 & $136 \pm 1$ & $26 \pm 1$ & $-125.2 \pm 4.1$ & $22.2 \pm 0.4$ & $2.8 \pm 0.1$ & $22.4 \pm 1.4$ \\
\hline
\end{tabular}


a new type of surface which possesses different chemistry (Kujawa et al. 2017; Szczerbińska et al. 2017). The newly produced layer was characterized by a very low contribution of polar components (Table 1). This phenomenon is common for the highly hydrophobic surfaces (Kujawa et al. 2017). Not only CA but also spreading pressure $(S)$ provides an insight into the wetting behavior of membranes. Established $S$ parameters were characterized by negative values and nonzero CA for all tested ceramic membranes, prior and after hydrophobization as well as utilization in separation process (Table 1) that is in good accordance with the scientific literature. The calculated values of S (for water as a testing liquid) were in the range of $-17.0 \pm 0.6 \mathrm{mN} \mathrm{m}^{-1}$ (pristine membrane before MF) to $-130.2 \pm 4.3 \mathrm{mN} \mathrm{m}^{-1}$ (membrane grafted with FC6 before MF). A small variation of the $\mathrm{S}$ has been noticed for samples used in the MF process. The negative values of $S$ are characteristics for the surfaces on which the wetting was not complete or when there is the lack of wetting (Bikerman 1963; Good 1975). The negative value of spreading pressure is a common phenomenon for the material with high hydrophobicity level. Erbin (1997) discussed this phenomenon in detail, showing how the hydrophobicity level can affect the $S$ value. The lower value of $S$ parameter for the more hydrophobic sample (C6 and FC6) is referred to the smaller basicity of the sample. Moreover, the roughness of the samples decreased after modification and that is linked to the silanization process, leading to the smoother surface, covered by organic nanolayer (Al-Gharabli et al. 2018; Koonaphapdeelert and $\mathrm{Li}$ 2007). On the other hand, it was noticed that membranes used in filtration process were characterized by slightly different parameters. In the case of samples modified by $\mathrm{C} 6$ and FC6, the minor reduction of the contact angle was noticed. As a consequence of these changes, an increase of surface free energy and its polar component has been also observed. Furthermore, the alteration of roughness for pristine membrane after microfiltration process was observed, with an increase of around 20\% (Table 1). The reason for these changes should be sought in the potential fouling during the filtration process.

\section{Material properties of polymeric membranes}

Similarly, polymeric samples were characterized in detail prior to and after an application in the air-gap membrane distillation separation process. Polymeric membranes PP10, PTFE20, and PTFE45, were utilized in the concentration process of lactose and whey solution realized by AGMD. All chosen membranes (Fig. 3) were porous and possessed hydrophobic character (Table 2). The porosity of the PP10 membrane was equal to $75 \%$. PTFE20 and PTFE45 were characterized by the porosity 62 and $80 \%$, respectively. The differences in the membrane morphology were related to the different fabrication method. PTFE membranes are expanded-film membranes made of polytetrafluoroethylene by the uniaxial or biaxial stretching process resulting in an interconnected pore structure (Kujawa et al. 2015). On the other hand, PP membrane differs significantly considering top (selective) and bottom side with the visible support layer (Fig. 3). In the case of ceramic membranes, it was emphasized that the filtration process of dairy products influenced the material properties of the samples (Table 1). The analog observation has been also found in the case of polymeric membranes (Table 2).

For both polymers, polypropylene, and polytetrafluoroethylene, an impact of the separation process on the material properties was noticed. As an effect of the AGMD process, a decrease of contact angle of about $10 \%$ was observed. More visible influence has been observed in the case of contact angle hysteresis (HCA). Comparing membranes before and after the separation process, an increase of contact angle hysteresis was observed (Table 2). That phenomenon can be related not only to the changes in the hydrophobicity of the surfaces but also to the physiochemistry and surface roughness parameters (Table 2). The biggest impact has been noticed for PTFE20 sample, due to the highest increase of RMS parameter. An increase of the polar component is related to the generation of the more hydrophilic surface. The polar component describes the interactions associated with induction (Debye), hydrogen, polar, and acid-base forces. It occurs in molecules possessing a permanent dipole moment. These molecules keep stable inequity in the electron density because of moderate electronegativities of the bonding partners, having simultaneously asymmetrical geometry (e.g., water). In the presented case, the elevation of the polar part of SFE after the process is associated with the presence of the traces of separated dairy products, visible on the SEM images (Fig. 3). An increase of roughness value also proves this observation. Similarly to the ceramic samples, negative values of spreading pressure were observed; however, for polymeric membranes much lower values were observed, in the range of $-91.6 \pm 3.0 \mathrm{mN} \mathrm{m}^{-1}$ (PP10 after separation process) to $-122.4 \pm 4.0 \mathrm{mN} \mathrm{m}^{-1}$ (PTFE45 after separation process) (Table 2). A slight reduction in absolute value of the $S$ parameters was related to the formation of foulant layer (Fig. 3) and an increase of hydrophilicity of the samples (Table 2).

\section{Transport and separation properties of ceramic membranes in filtration process}

At the outset of the measurements, the transport properties for the pristine ceramic membranes with $5 \mathrm{kD}$ and $300 \mathrm{kD}$ MWCO were determined (Fig. 4). It can be noticed (Fig. 4) that the pore size of the membrane significantly impacts the 


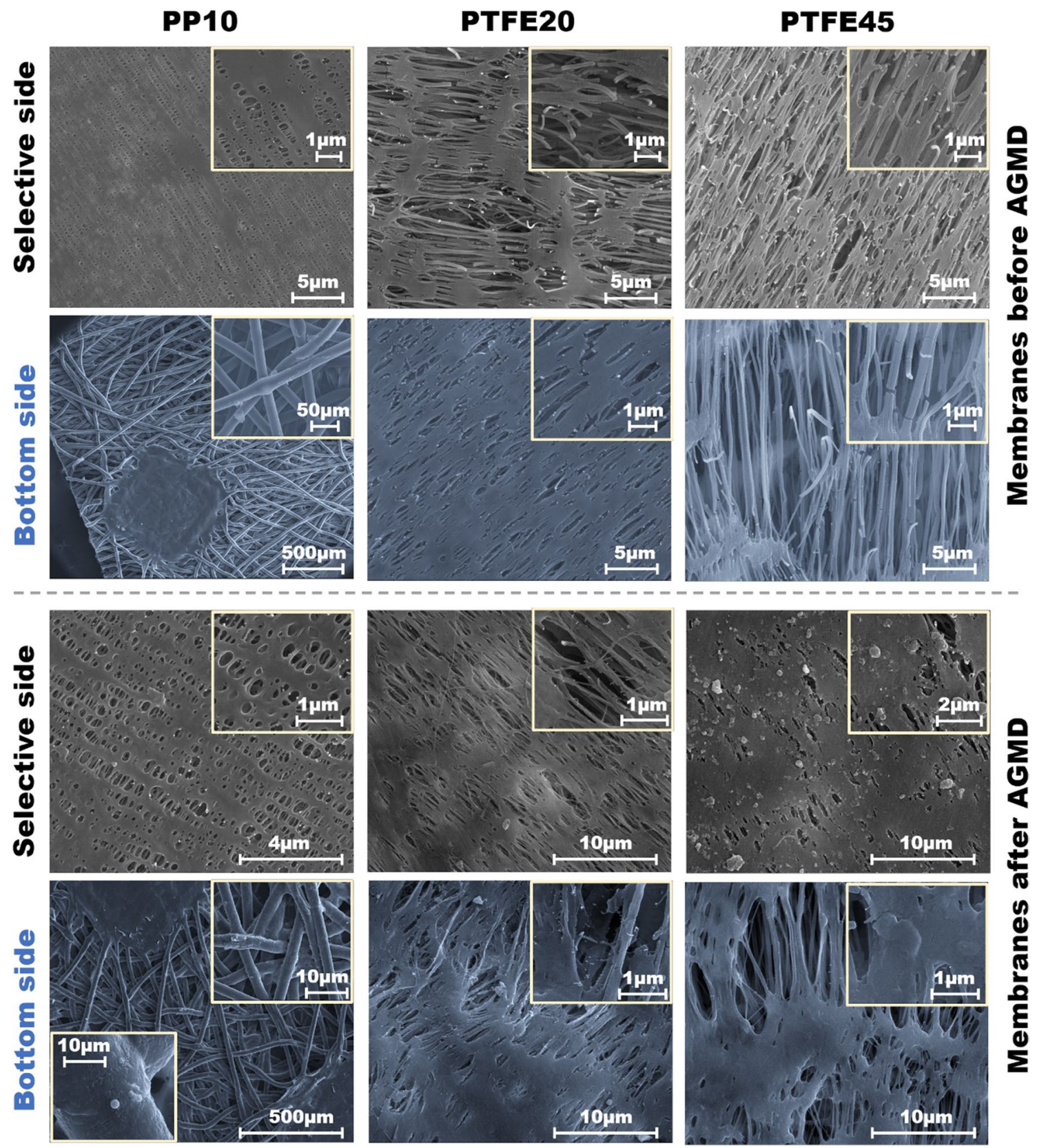

Fig. 3 SEM images of polymeric membrane samples prior and after the utilization in AGMD with 5 wt $\%$ of pure lactose aqueous solution

Table 2 Physicochemical properties of applied polymeric membranes

\begin{tabular}{lcccccc}
\hline Membrane & CA $(\mathrm{deg})$ & $\mathrm{HCA}(\mathrm{deg})$ & $\mathrm{S}\left(\mathrm{mN} \mathrm{m}^{-1}\right)$ & $\mathrm{SFE}\left(\mathrm{mN} \mathrm{m}^{-1}\right)$ & $\mathrm{SFE}^{\text {polar }}\left(\mathrm{mN} \mathrm{m}^{-1}\right)$ & $\mathrm{RMS}(\mathrm{nm})$ \\
\hline \multicolumn{2}{l}{ Membranes before AGMD process } & & & & \\
PP10 & $113 \pm 1$ & $36 \pm 1$ & $-101.3 \pm 3.3$ & $51.2 \pm 0.4$ & $8.7 \pm 0.2$ & $55 \pm 3$ \\
PTFE20 & $121 \pm 1$ & $34 \pm 1$ & $-110.3 \pm 3.6$ & $42.3 \pm 0.3$ & $8.6 \pm 0.2$ & $70 \pm 2$ \\
PTFE45 & $133 \pm 1$ & $32 \pm 1$ & $-122.4 \pm 4.0$ & $29.9 \pm 0.3$ & $8.7 \pm 0.3$ & $65 \pm 2$ \\
Membranes after AGMD process & & & & \\
PP10 & $105 \pm 1$ & $54 \pm 1$ & $-91.6 \pm 3.0$ & $59.3 \pm 0.4$ & $9.0 \pm 0.2$ & $105 \pm 2$ \\
PTFE20 & $111 \pm 1$ & $52 \pm 1$ & $-98.9 \pm 3.3$ & $57.9 \pm 0.4$ & $13.6 \pm 0.2$ & $120 \pm 3$ \\
PTFE45 & $120 \pm 1$ & $40 \pm 1$ & $-109.2 \pm 3.6$ & $43.7 \pm 0.3$ & $9.4 \pm 0.2$ & $103 \pm 3$ \\
\hline
\end{tabular}




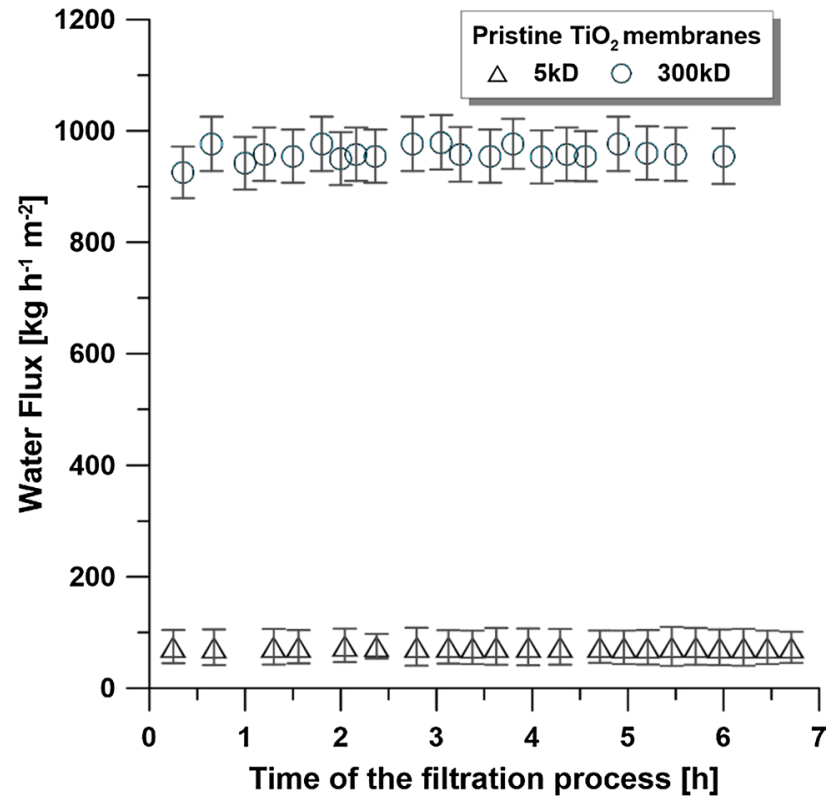

Fig. 4 Evolution of water flux during the filtration process with ceramic membranes

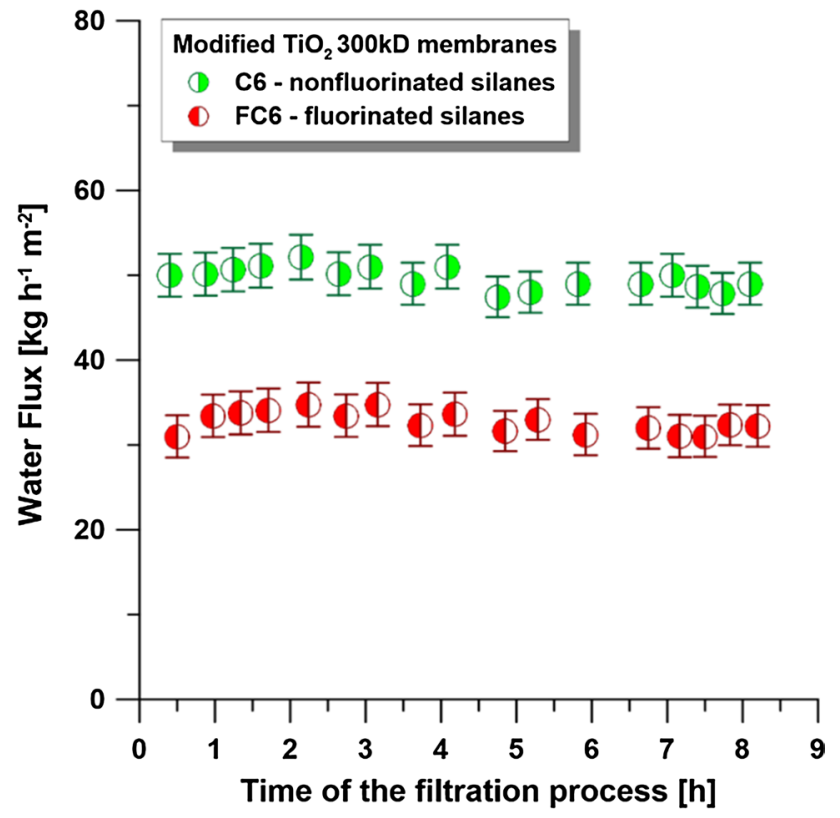

Fig. 5 Evolution of water flux during the microfiltration process with modified membranes

transport properties of investigated membranes. Ceramic membranes with smaller pores $(\mathrm{MWCO}=5 \mathrm{kD}$ what corresponds to ca. $3 \mathrm{~nm}$ diameter) were characterized by an average flux of water equal to $74.4 \mathrm{~kg} \mathrm{~h}^{-1} \mathrm{~m}^{-2}$. For a more open membrane, possessing pore size of around $200 \mathrm{~nm}$ $(\mathrm{MWCO}=300 \mathrm{kD})$, an average flux of water was around
$960.3 \mathrm{~kg} \mathrm{~h}^{-1} \mathrm{~m}^{-2}$. For that reason, the functionalization process was implemented only for $300 \mathrm{kD}$ membranes.

The modification process with two types of grafting agents $1 \mathrm{H}, 1 \mathrm{H}, 2 \mathrm{H}, 2 \mathrm{H}$-perfluorooctyltriethoxysilane and octyltriethoxysilane was studied and the established data are shown in Fig. 5. Comparing the transport properties for pristine (Fig. 4) and modified (Fig. 5) membranes the significant reduction of the transport performance was observed. This fact was related to the change of the natural hydrophilic ceramic membranes into hydrophobic ones (Table 1). Furthermore, these changes were related to the reduction of the pores size after the grafting process. However, the main impact was associated with the introduction in the chemistry of the material. $\mathrm{TiO}_{2} 300 \mathrm{kD}$ pristine membrane was characterized by pore size $190 \mathrm{~nm}$, after functionalization the pore size was reduced to $186 \mathrm{~nm}$. It revealed that membranes were still in the microfiltration range. In the case of the application of non-fluorinated grafting agent (C6), water flux decreased ca. 20 times comparing to the pristine membrane. However, the introduction of more hydrophobic molecules FC6 onto the membrane surface as well as into the pores resulted in the reduction of water flux of almost 30 times (Figs. 4, 5). Generally, there is no big difference between transport features of both hydrophobized membranes. This is very important from the potential application point of view. Taking into account the possible application in food and dairy industry, an utilization of fluorine-free material is required. It can be stated that the modified membrane with $\mathrm{C} 6$ molecules can be utilized in the filtration process with higher effectiveness comparable to the samples grafted with FC6 (Fig. 5).

The compositions of the feed solutions were associated with the level of the lactose in the real products-raw and condensed milk. Lactose content in the raw milk is in the range of 4.6-5.1 wt\% (Hausmann et al. 2014; Kazmierski and Corredig 2003; Królczyk et al. 2016; Rezaei et al. 2014). However, in the condensed product the lactose level is between 10 and $12 \mathrm{wt} \%$. The following concentrations 5, 10 and $12 \mathrm{wt} \%$ of lactose for both single (i.e. lactose) and multicomponent mixture (i.e. whey) were chosen. According to the data obtained and presented in Fig. 6, it can be seen that physiochemistry of the sample has the most significant impact on the transport properties. Pristine, hydrophilic membrane was characterized by a contact angle of around $40^{\circ}$ and the highest values of permeate flux (Fig. 6). A decrease of transport properties was observed with the increase of lactose concentration in the feed solutions. To show the mentioned differences in a more clear way, normalized fluxes were also presented. The flux of pure water through membranes was equal to $951 \pm 20 \mathrm{~kg} \mathrm{~h}^{-1} \mathrm{~m}^{-2}$; however, for lactose aqueous solutions the fluxes changed in the following way: from $570 \pm 25$ to $532 \pm 26$, and to 

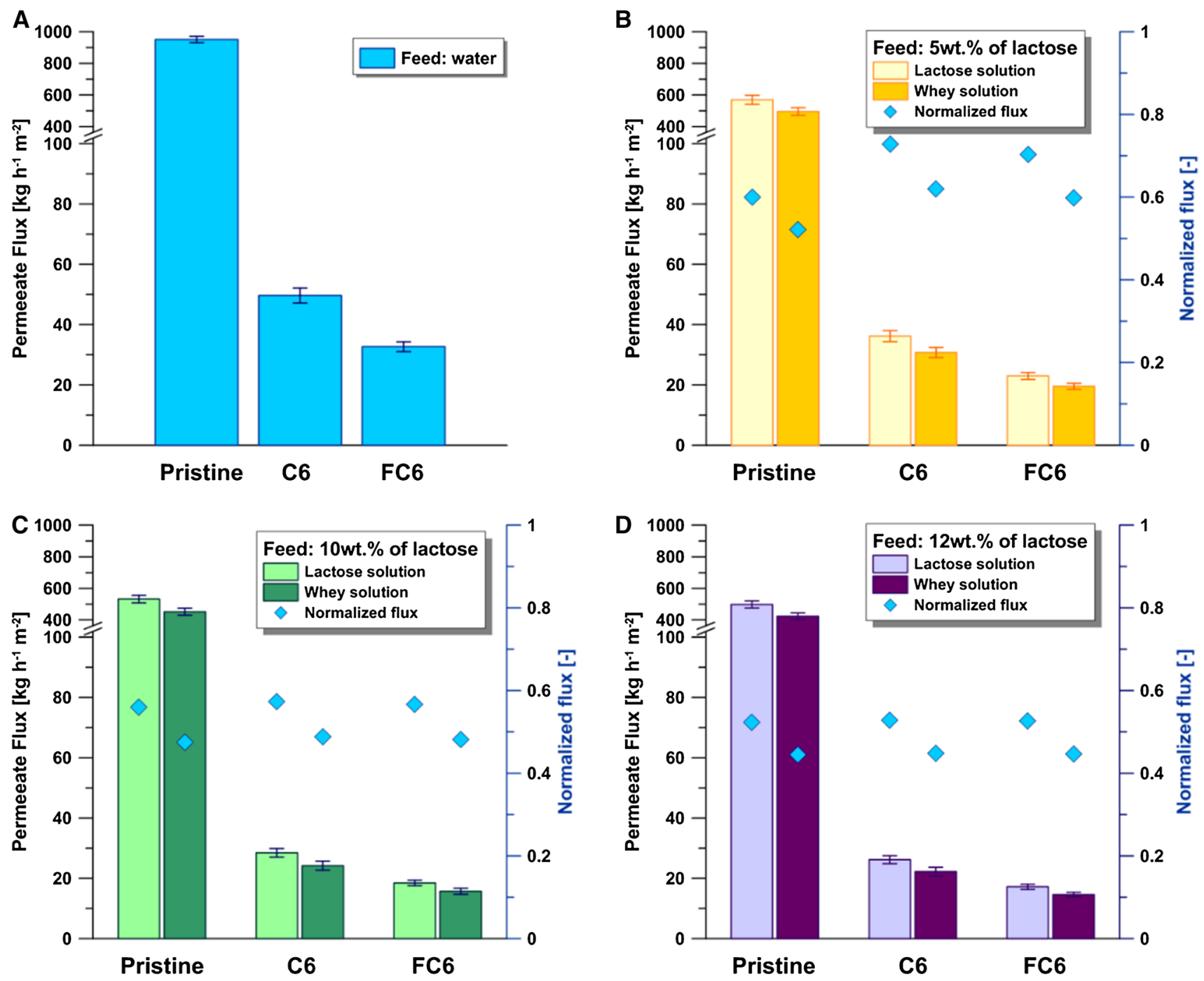

Fig. 6 Transport properties of pristine and modified $\mathrm{TiO}_{2} 300 \mathrm{kD}$ ceramic membranes in contact with water and aqueous solutions of lactose (pure lactose) and whey (whey powder containing $70 \%$ of lactose) during microfiltration process

$498 \pm 23 \mathrm{~kg} \mathrm{~h}^{-1} \mathrm{~m}^{-2}$ for the 5,10 and $12 \mathrm{wt} \%$ of lactose, respectively.

Slightly smaller values have been found for whey solutions. In this latter case, the flux diminution in the range of $15-18 \%$ was noticed. For the hydrophobized membranes with nonfluorinated grafting agents, the permeate fluxed decreased from ca. $50 \pm 2.5 \mathrm{~kg} \mathrm{~h}^{-1} \mathrm{~m}^{-2}$ while contacting water to $36.2 \pm 1.8 \mathrm{~kg} \mathrm{~h}^{-1} \mathrm{~m}^{-2}$ when the $5 \mathrm{wt} \%$ lactose solution was used. Furthermore, for more concentrated feeds, i.e. 10 and $12 \mathrm{wt} \%$ the permeate fluxes were equal to $28.5 \pm 1.4 \mathrm{~kg} \mathrm{~h}^{-1} \mathrm{~m}^{-2}$ and $26.2 \pm 1.3 \mathrm{~kg} \mathrm{~h}^{-1} \mathrm{~m}^{-2}$, accordingly. The most hydrophobic samples possessing a contact angle equal to $142^{\circ}$ were characterized by water flux above $32 \pm 1.6 \mathrm{~kg} \mathrm{~h}^{-1} \mathrm{~m}^{-2}$. Nevertheless, the permeate fluxes for lactose solutions were in the range of $23 \pm 1.1-17.2 \pm 0.8 \mathrm{~kg} \mathrm{~h}^{-1} \mathrm{~m}^{-2}$ (Fig. 6). Similarly to the hydrophilic membranes, transport of whey across the hydrophobic membranes was diminished compared to the transport of lactose solutions.

Taking into account the separation properties of the tested membranes (Fig. 7), it can be seen that lactose rejection (Eq. 2) was improved after the functionalization process. Turbidity coefficient (Eq. 1) and lactose rejection coefficient were determined based on the refractometric analysis, $R_{\mathrm{L}}$ (Eq. 2).

After $7 \mathrm{~h}$ of the filtration, the rejection coefficient for a nonmodified membrane was equal to $71 \%$. On the other hand, highly hydrophobic samples of ceramic modified with C6 and FC6 molecules were characterized by lactose rejection coefficient $88 \%$ and $89 \%$, respectively. Moreover, the product 


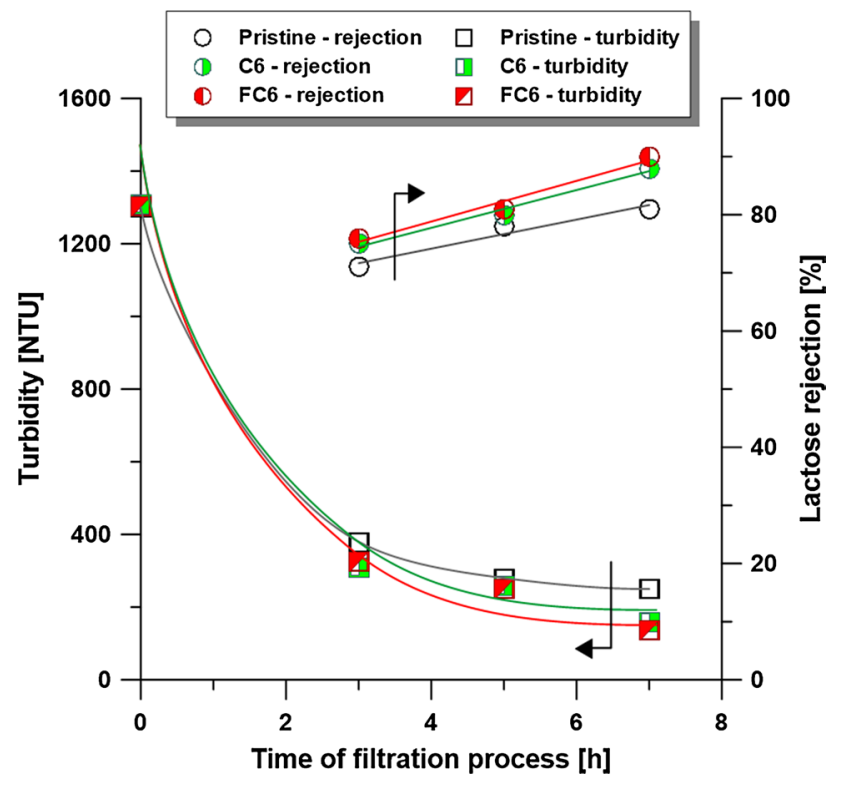

Fig. 7 Separation properties of pristine and hydrophobized ceramic membranes. Feed solution: $5 \mathrm{wt} \%$ lactose (pure lactose)

after filtration process with FC6 membrane was characterized by turbidity lower by $45 \%$ compared with the results for the pristine membrane (Fig. 7).

\section{Transport and separation properties of polymeric membranes in air-gap membrane distillation process}

The air-gap membrane distillation was also applied to the concentration of dairy products. Model solutions of lactose and whey at various concentration were used as feed mixtures (Fig. 8). Prior to the AGMD separation process, membranes were tested in contact with pure water. Both types of the membrane materials polypropylene (PP) and polytetrafluoroethylene (PTFE) are slightly different with regards to morphology as it was presented in Fig. 3. PP possesses the lowest pore size of $0.10 \mu \mathrm{m}$ and has also an additional support layer on the reverse side. Such membrane morphology was responsible for the lowest water transport (Fig. 8). An average flux was equal to $1.20 \pm 0.10 \mathrm{~kg} \mathrm{~h}^{-1} \mathrm{~m}^{-2}$. On the other hand, polytetrafluoroethylene membranes were characterized by the water flux of $2.31 \pm 0.11 \mathrm{~kg} \mathrm{~h}^{-1} \mathrm{~m}^{-2}$ and $5.52 \pm 0.19 \mathrm{~kg} \mathrm{~h}^{-1} \mathrm{~m}^{-2}$ for PTFE20 and PTFE45, respectively. To follow the differences in transport properties, normalized fluxes were presented in Fig. 8. The structures of the PTFE membranes are more open and possess different morphology of the selective layer than the PP10 membrane (Fig. 3). Although PTFE45 membrane was characterized by the highest hydrophobicity level (Table 2), the observed highest flux was related to a very open structure (the biggest pores and the highest porosity). It should be highlighted that no wetting was observed and membranes were suitable for separation in AGMD process. Quite a high hysteresis of contact angle for all samples being in the range of $32-36^{\circ}$ was associated with the relatively high roughness of the surface samples. While all samples were hydrophobic, the high contribution of polar part of the surface free energy (17\% for PP10 and 29\% for PTFE45) was observed. This fact can influence higher membrane ability to fouling during the separation process. Furthermore, in the case of whey flux reduction, the explanation needs to be linked with protein presence in the solution. These proteins can aggregate on the membrane and enhance fouling effect (Mourouzidis-Mourouzis and Karabelas 2006, 2008; Steinhauer et al. 2015). Mourouzidis-Mourouzis et al. $(2006,2008)$ discussed in detail an impact of whey protein aggregates phenomenon and its involvement in the fouling formation during the filtration process.

Concerning the separation of lactose and whey solutions, it was noticed that the similar attitude to the reduction of ceramic membranes performance with the increase of lactose concentration in the separated system was observed (Fig. 8). This fact is related to the reduction of driving forces during the process (Kujawa and Kujawski 2015). The reduction of permeate flux from $5.52 \pm 0.19 \mathrm{~kg} \mathrm{~h}^{-1} \mathrm{~m}^{-2}$ for water to $4.73 \pm 0.15 \mathrm{~kg} \mathrm{~h}^{-1} \mathrm{~m}^{-2}$ ( $5 \mathrm{wt} \%$ of lactose), $4.26 \pm 0.13 \mathrm{~kg} \mathrm{~h}^{-1} \mathrm{~m}^{-2}$ (10 wt\% of lactose), and $3.48 \pm 0.10 \mathrm{~kg} \mathrm{~h}^{-1} \mathrm{~m}^{-2}$ (12 wt\% of lactose) for PTFE45 membrane has been observed (Fig. 8). The PTFE45 membrane was characterized by the highest reduction of transport properties. Similar findings were reported by Hausmann et al. (2013a, b) during the MD process of skim milk and lactose solutions. For the PTFE $0.5 \mu \mathrm{m}$ permeate flux of milk and whey were equal to $12 \mathrm{~kg} \mathrm{~h}^{-1} \mathrm{~m}^{-2}$ and $20 \mathrm{~kg} \mathrm{~h}^{-1} \mathrm{~m}^{-2}$, respectively. However, the observed higher flux was related to the smaller thickness of the membrane equal to $20 \mu \mathrm{m}$ and bigger pore size $(0.50 \mu \mathrm{m})$. PTFE membranes utilized in our research were characterized by $0.45 \mu \mathrm{m}$ pore size and thickness of $80 \mu \mathrm{m}$. Nevertheless, the flux for whey has been found to be ca. $60 \%$ smaller (Hausmann et al. 2013a, b). The lowest reduction rate was found for PP10 membrane. This parameter is directly related to the contribution of polar component of the SFE for unused materials.

All tested membranes were characterized by a very high selectivity, the retention of the lactose from the $5 \mathrm{wt} \%$ solution was in the range of 92-99\%. However, at the end of the process the $R_{\text {Lactose }}$ was ca. $99 \%$.

Also, the measured turbidity of the permeate solutions was very low between 41 NTU for PTFE20 and 14 NTU for PTFE45, respectively. The value of the turbidity for an initial feed solution was around 1300 NTU (Fig. 9). The parameters used to assess the separation properties of the 


\section{A}
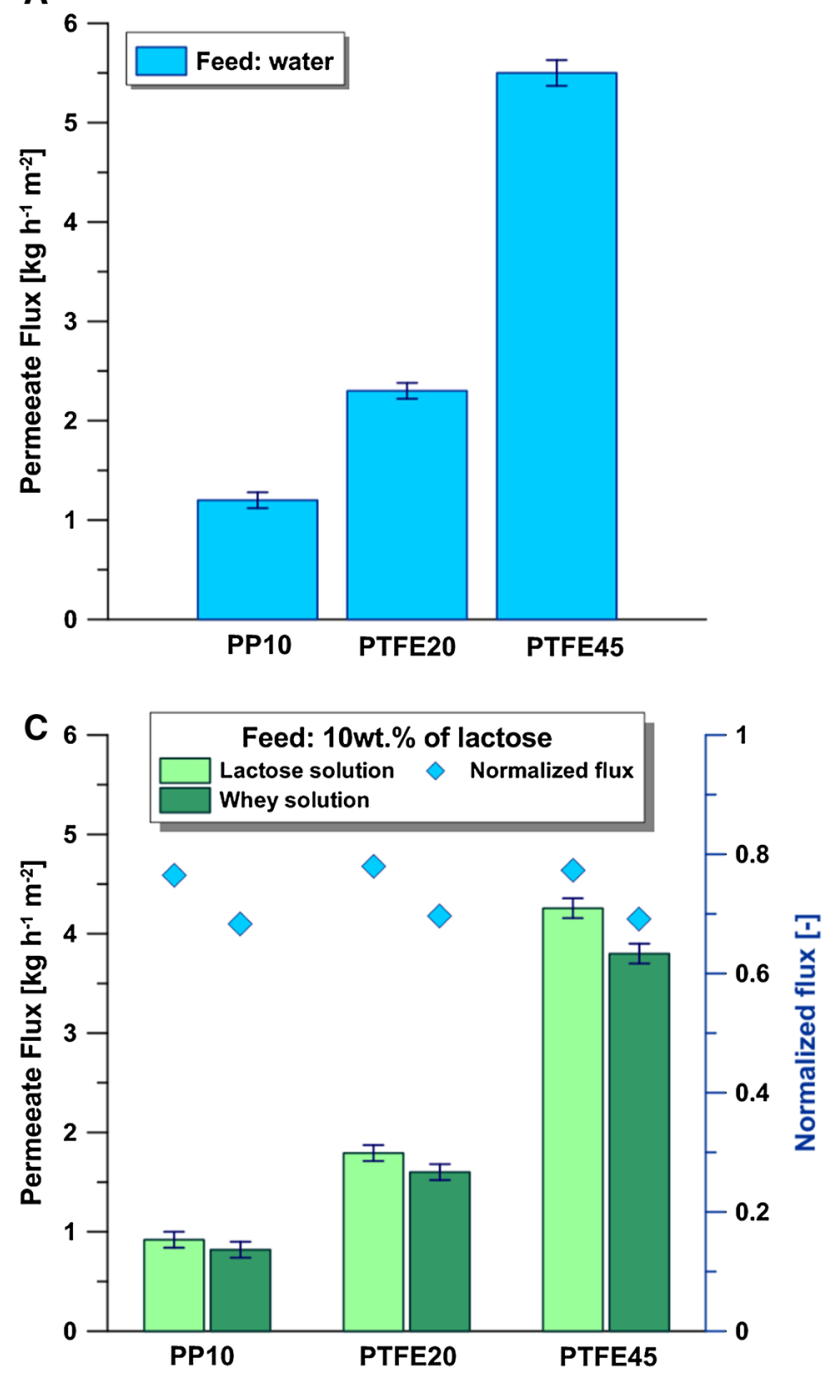
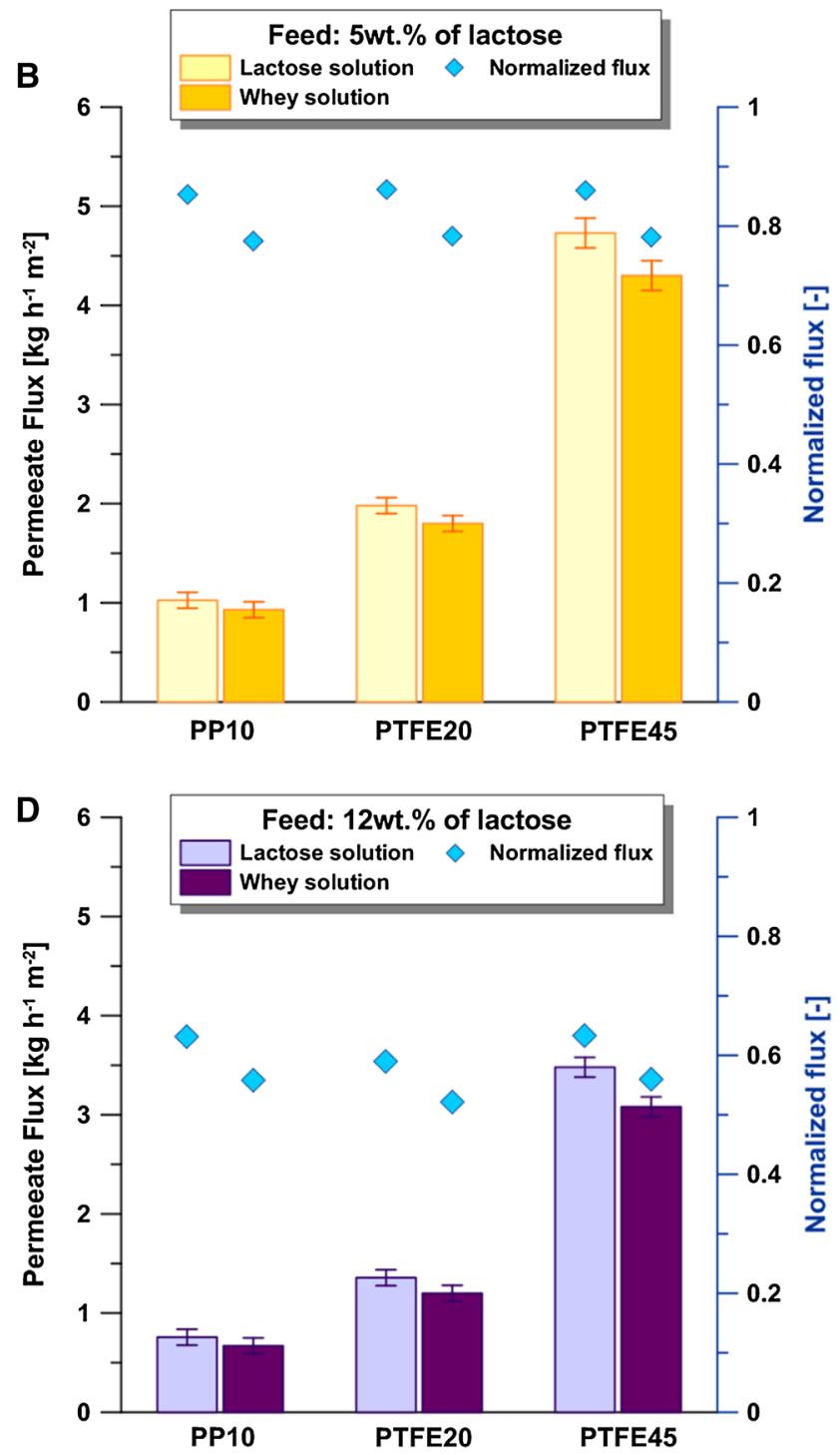

Fig. 8 Transport properties of polymeric porous hydrophobic membranes in contact with water and aqueous solutions of lactose (pure lactose) and whey (whey powder containing $70 \%$ of lactose) during AGMD process

membranes, i.e. $\mathrm{R}_{\mathrm{L}}$ and $\mathrm{TC}$ were found to be the best for PTFE45. On the other hand, lactose rejection and turbidity were comparable for PP10 and PTFE20 (Fig. 9).

\section{Fouling studies}

The fouling susceptibility of membranes is an important factor influencing the membrane performance (Królczyk et al. 2016; Laqbaqbi et al. 2017). During the membrane processes, flux declines due to the membrane fouling, raising the maintenance and operation costs (Plisko et al. 2018; Safarpour et al. 2016), causing important shortcomings of membrane utilization, particularly in the separation of colloidal and protein solutions (Hausmann et al. 2011, 2013a, b, 2014, Rezaei et al. 2014; Tomaszewska and
Białończyk 2013). Therefore, a great attention has been paid to the improvement of the antifouling capability of membranes. Various parameters can be assessed to evaluate the antifouling ability of membranes, e.g., flux recovery ratio or flux decline $\left(\mathrm{FD}_{n}\right)$. The value of $\mathrm{FD}_{n}$ depends on the type of membrane process, membrane material and its morphology as well as on the type of separation process (Laqbaqbi et al. 2017). In this work, SEM imaging and calculation of normalized flux decline parameter (Eq. 6) were applied to examine the fouling vulnerability of tested membranes.

$\mathrm{FD}_{n}=\left(1-\frac{J_{\mathrm{f}}}{J_{0}}\right) \cdot 100[\%]$ 


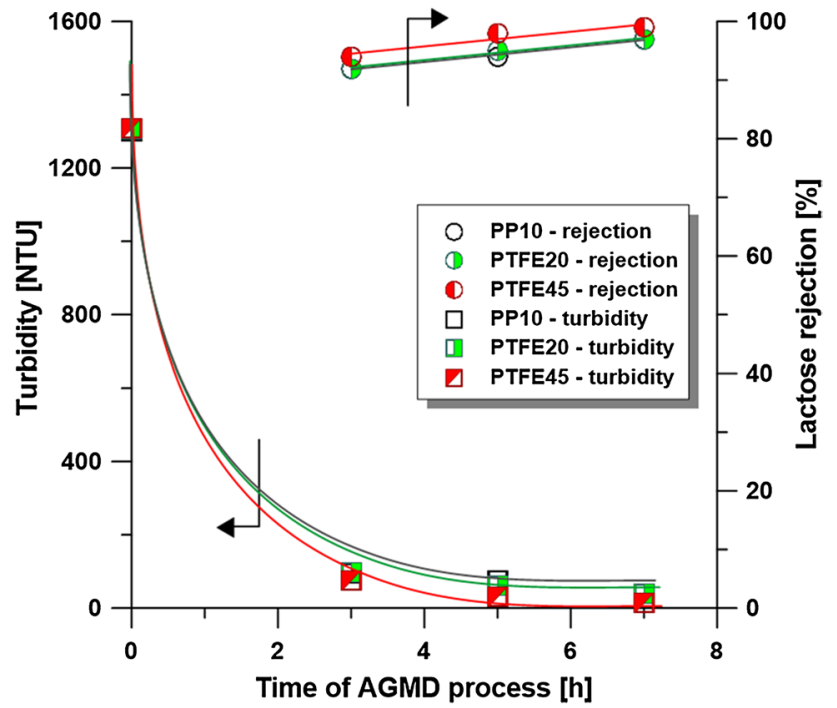

Fig. 9 Separation properties of polymeric membranes. Feed solution: $5 \mathrm{wt} \%$ lactose (pure lactose)

where $J_{0}$ and $J_{\mathrm{f}}$ are initial and final permeate fluxes.

Furthermore, to evaluate antifouling features of the membranes more in detail, the following parameters were calculated and compared: flux recovery ratio (FRR) (Eq. 7), reversible flux decline ratio (RDR) (Eq. 8) and irreversible flux decline ratio (IRDR) (Eq. 9) (Camacho et al. 2013; Shafi et al. 2017; Zhao et al. 2014).

$\mathrm{FRR}=\left(\frac{J_{2}}{J_{1}}\right) \cdot 100[\%]$

$\operatorname{RDR}=\left(1-\frac{J_{\mathrm{p}}}{J_{1}}\right) \cdot 100[\%]$

$\operatorname{IRDR}=\left(1-\frac{J_{2}}{J_{1}}\right) \cdot 100[\%]$, where $J_{1}$ and $J_{2}$ are pure water flux and pure water flux after membrane washing; $J_{\mathrm{p}}$ is permeate flux.

\section{Microfiltration process with ceramic membranes}

The decline of flux during microfiltration and ultrafiltration of whey can be linked with the membrane fouling, including pore plugging, deposition or adsorption of proteins in the pores of the membrane (Rezaei et al. 2014), as well as with concentration polarization phenomenon.

In this work, the flux decline for ceramic membranes tested in microfiltration process of $12 \mathrm{wt} \%$ aqueous solution of whey was equal to $25.5 \%$ for pristine membrane and $28.1 \%$ and $31.2 \%$ for C6 and FC6 membranes, respectively. However, in the case of the lactose solution, the flux decline was much lower and equal to about $5 \%$. Moreover, the whey flux decline appeared to follow the growth of the fouling layer and increase the deposited amount of solids (Fig. 10). According to the scientific literature (Hausmann et al. 2013a, b), the flux under such conditions is controlled by the diffusion resistance in the fouling layer, independently of its thickness (Hausmann et al. 2013a).

Flux recovery ratio values were in the range of $41-67 \%$ for ceramic membranes (Fig. 11). Taking into account the contacted feed mixtures, with an increase of lactose concentration in the model solutions, diminution of FRR factors was observed. The best antifouling membrane performance has been found for the ceramic membrane modified by FC6 ( $F R R=66.8 \%$, feed-5\% lactose).

The creation of the foulant layer on the ceramic membranes was related to the changes in contact angle values and their hysteresis (Table 1). Furthermore, an increase in surface free energy has been also observed. Subsequently, the higher contribution of polar part of SFE was linked to the presence of the organic layer on the surface sample (Fig. 10). Traces of fouling layer can be linked with the increase of surface roughness parameters (RMS) identified by AFM measurements. The changes in RMS parameters were found
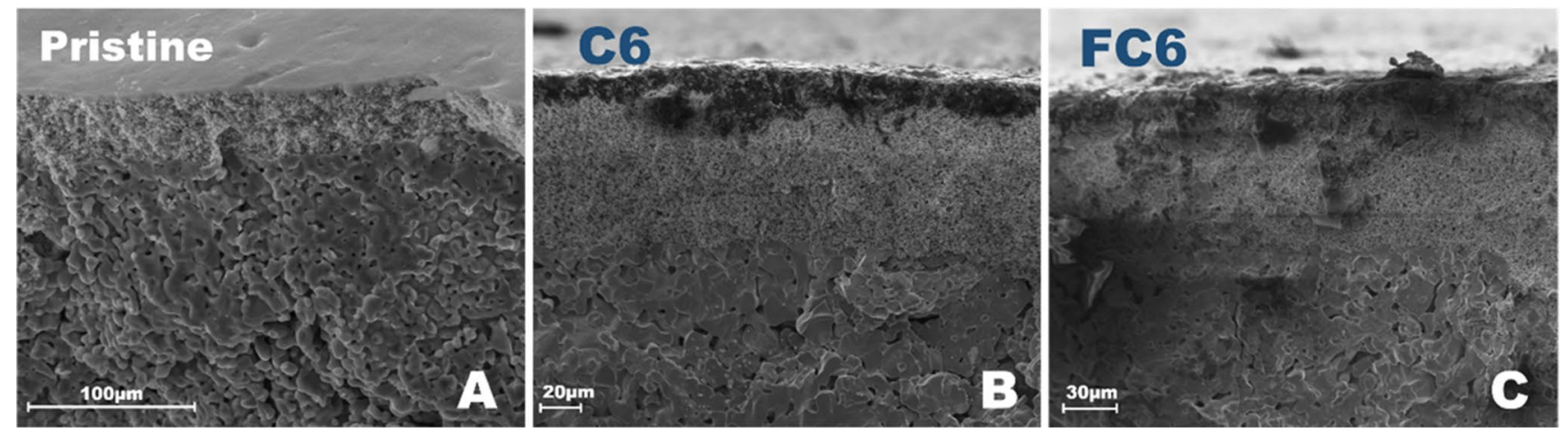

Fig. 10 SEM images of ceramic membranes-pristine (a), C6 (b) and FC6 (c) after the microfiltration process with 5 wt\% whey as a feed solution 


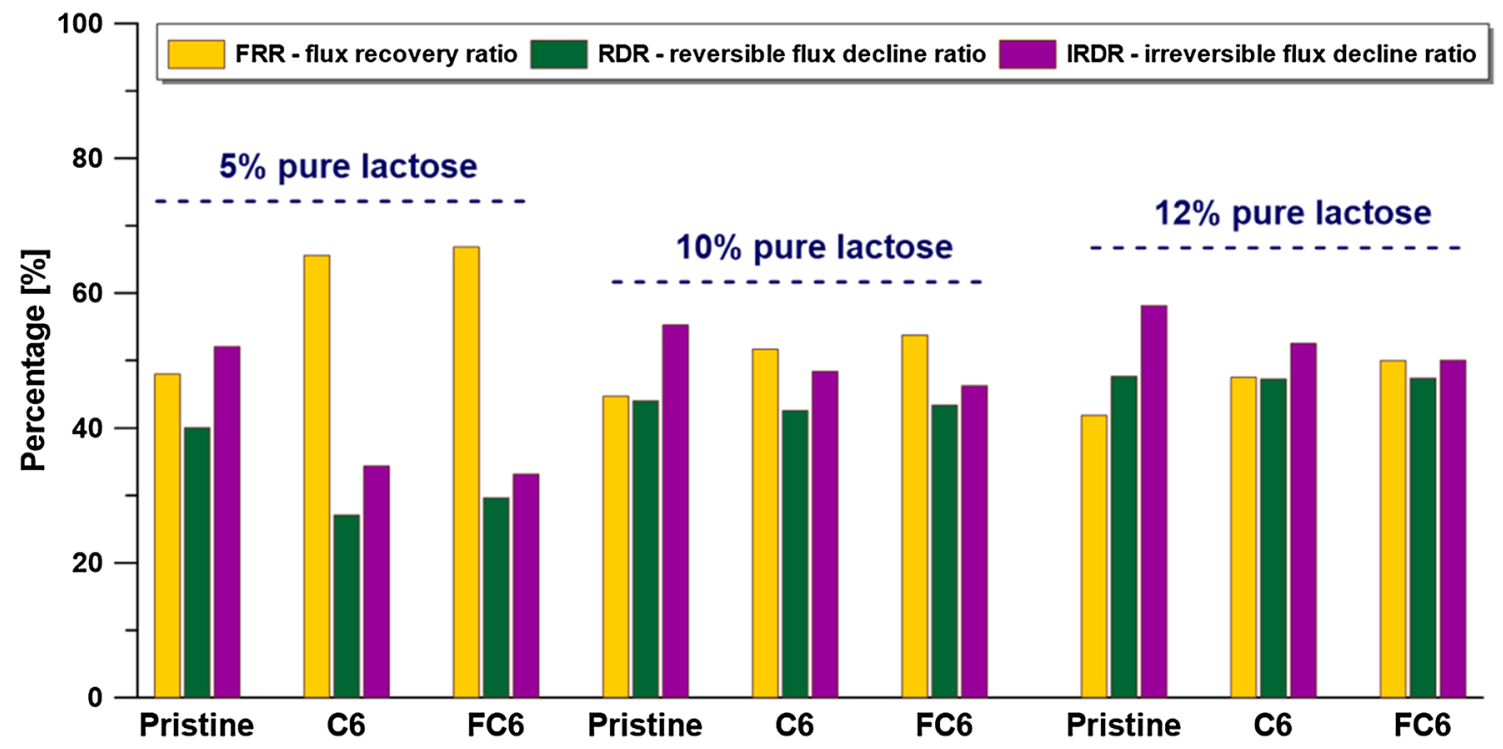

Fig. 11 Summary of flux recovery ratio (FFR), reversible flux decline ratio (RDR), and irreversible flux decline ratio (IFDR) for ceramic membranes tested in microfiltration process

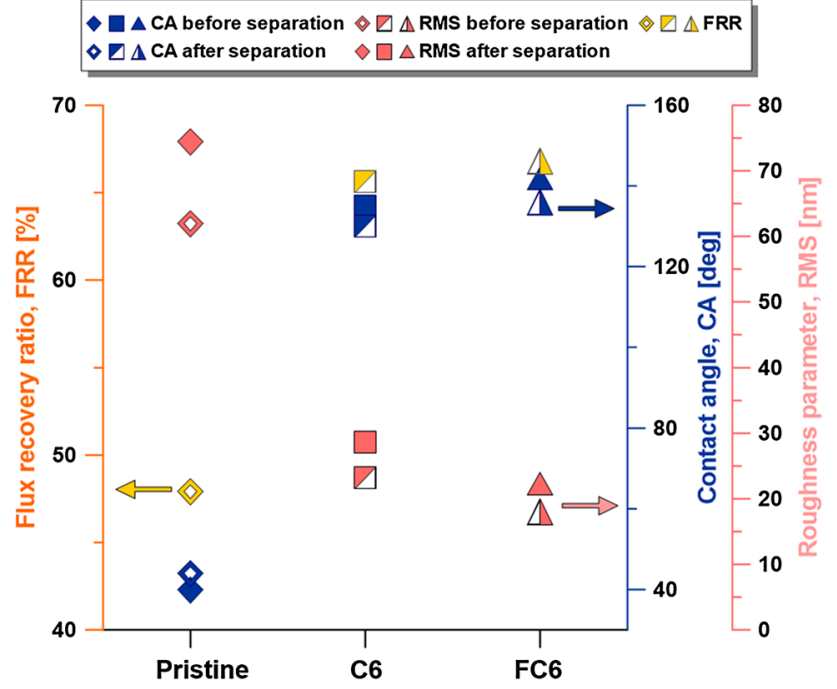

Fig. 12 Correlation between antifouling properties (FRR) and material features of the investigated ceramic membranes. Contact angle values and roughness parameters were determined before and after the separation process of $5 \%$ pure lactose model solution

to be in the range of $20-24 \%$, for pristine and FC6 samples, respectively.

The significant variations of the antifouling capability of membranes are related to the differences in the material and physicochemical properties of membrane surface: surface roughness and hydrophobicity level and surface free energy. Figure 12 presents the correlation between FRR, average roughness, and contact angle. Upon the increase of hydrophobicity level in the case of ceramic samples, FRR and
CA values were improved. Subsequently, as a result of the grafting process with fluorinated compounds, reduction of RMS was noticed. A decrease of roughness generated significant improvement in FRR factor due to the reduction of a tendency to protein accumulation on the surface heterogeneities. The material features become more important after application of membranes in separation process (Fig. 12) due to the permanent deposition of fouling layer.

\section{Membrane distillation with polymeric membranes}

The flux decline and fouling issues in MD process have been noticed and extensively studied by Hausmann et al. (2011, 2013a, b, 2014). Authors highlighted that fouling phenomena in the MD process are different from those occurred in pressure-driven processes such as reverse osmosis. Lower operating pressures in the membrane distillation process positively influence the fouling susceptibility, i.e., by a formation of a less dense and more easily removed layer of foulants. Moreover, in MD process only volatile compounds are transported across the membrane pores, and due to that the possibility of pores fouling is reduced. On the other hand, it was revealed that penetration of foulants into the membrane structure could take place in some cases (Gryta 2008; Hausmann et al. 2013a, b). There is a necessity for a better understanding of how dairy components (e.g., skim milk, whey) interact with membranes and accumulate at the surface of the membrane. As a result of better understanding of fouling, the possibility of better control and finally the reduction of fouling can be achieved. Hausmann and co-workers 
(Hausmann et al. 2013a, b) suggested that depending on the type of separated dairy products (e.g., skim milk, whey, lactose solutions) the fouling layer properties as well as the mechanism of fouling layer formation can be different.

Taking into account the polymeric membranes used in AGMD process, the measured flux decline was in the range of $37.5-42.3 \%$ for whey and between 23.2 and $26.5 \%$ for lactose solutions, respectively. Moreover, lactose solution did not indicate an important sign of fouling (Fig. 5), suggesting that the flux reduction was more likely due to membrane morphology changes (Hausmann et al. 2014, 2013a, b). These observations are in good accordance with the literature data and are also supported by the data established from the material analysis (Table 2). An insignificant coating of the membrane surface was noticed during the separation of lactose solutions (Fig. 3); however, in the case of whey the foulant layer was noticeable (Fig. 13). The highest $\mathrm{FD}_{\mathrm{n}}$ was noticed for PTFE45 sample and the smallest one for PP10 membrane. The reason of observed the highest value for PTFE material is the negative charge of PTFE that can lead to the charge interactions with salts present in whey (Hausmann et al. 2013a; Jucker et al. 1996). When the protein layer accumulates, the proteins could interact with each other by salt bridges with various salts adsorbed on the surface of the membrane. Based on the literature data (de la Fuente et al. 2002), the whey proteins are able to accumulate at a high concentration forming a layer close to the membrane surface. Furthermore, the possible mechanism of the presented fouling might be related to the whey protein aggregation in the course of experiment depending on the feed temperature and concentration (Karleskind et al. 1995; Kazmierski and Corredig 2003; Moro et al. 2001). Also, fouling is dominated by whey-protein-lactose-calcium interactions. In the case of lactose, it can interact directly with proteins by changing or disrupting their hydrogen bonding networks (Yorgun et al. 2008). The presence of sugars (i.e. lactose) causes the reduction of water activity which makes water-protein interaction less efficient; therefore, lactose can interact with proteins directly by hydrogen bonds. In Fig. 13, the thick fouling layer on the PP10
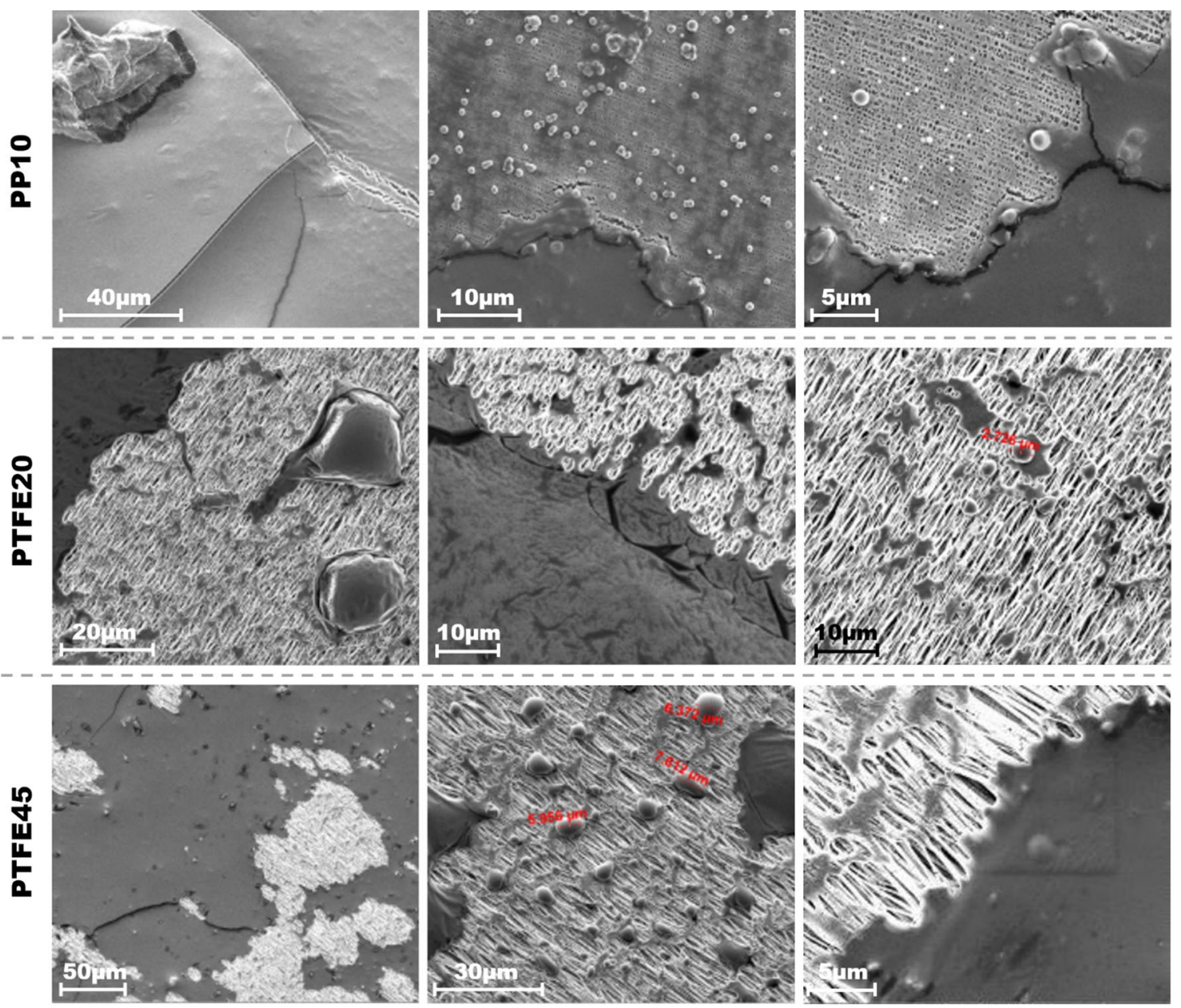

Fig. 13 SEM images of polymeric membranes-PP10, PTFE20, and PTFE45 after AGMD process with 5 wt $\%$ whey as the feed solution 
membrane can be seen. Furthermore, the presence of clean patches and randomly distributed nucleations was detected. The presented observations are revealed by the roughness parameters that changed significantly for this sample. RMS increased from $55 \mathrm{~nm}$ to $105 \mathrm{~nm}$ after utilization in AMGD. Also, the HCA increased from $36^{\circ}$ to $54^{\circ}$ (Tables 1 and 2). On the SEM images of PTFE20 membrane, a clear border between the clean patch and fouling layer was found. It was related to the higher hydrophobicity of the material. Nucleation sites (size ca. 2.3-2.7 $\mu \mathrm{m}$ ) have been found on the nodes and between fibers of the polymer. The highest vulnerability to fouling was observed in the case of the most hydrophobic PTFE45 membrane $\left(\mathrm{FD}_{n}=42.3 \%\right)$. In the SEM images, the randomly distributed nonfouled areas can be also observed (Fig. 13). The distinct separation line between fouling layers and clean areas can be related to the chemistry of the sample. The nucleation sites were bigger for PTFE45 membrane than for PTFE20 one and were in the range of 3.0-7.6 $\mu \mathrm{m}$. These nucleation sites most likely reduced the hydrophobicity and promoted spreading of the foulants and subsequent fouling.

The flux recovery ratio, reversible flux decline ratio, and irreversible flux decline ratio were calculated to achieve better description of the fouling capability for polymeric membranes tested in AGMD process (Fig. 14). Considering the polymeric membranes investigated, the best one was PTFE20 (FRR $=82.6 \%$, feed-5\% lactose). The reversible fouling aroused from the reversible protein adsorption and it can be removed by a simple hydraulic cleaning. However, the reversible fouling is carried by rigid adsorption of protein molecules on the surface or entrapment of protein molecules in pores (Plisko et al. 2018; Safarpour et al. 2016). For that reason, the significant impact of the type of feed solution was noticed. At higher concentration of lactose an increase of RDR and IRDR was found. For ceramic membranes and microfiltration experiments, RDR values were in the range of $27-47 \%$ whereas IRDR values were in the range of $36-58 \%$. Taking into account one type of the feed solution, it was seen that pristine membrane possessed the highest value of RDR and IRDR parameters (Fig. 14). For polymeric membranes, much smaller RDR and IRDR factors were obtained. RDR were found in the range of $14-41 \%$; however, IRDR were in the range of $18-45 \%$. A slight impact of the membrane material was also noticed, namely for PP10 higher values of evaluated parameters were observed. On the other hand, the pore size of the PTFE membrane has no influence on the antifouling properties.

Similarly, to the ceramic samples, in the case of polymeric ones, an important impact of material and physicochemical features of membrane surface on fouling ability has been noticed (Fig. 15). However, the mentioned influence was not such significant like for the ceramic membranes tested in microfiltration process. Substantial diminution in CA and RMS was found after separation processes. This observation was supported by the determined higher value of irreversible flux decline for the pristine membrane in the case of the ceramic sample and PP10 in the case of polymeric ones (Figs. 11 and 12). For these samples, the biggest reduction of CA and RMS was also noticed.

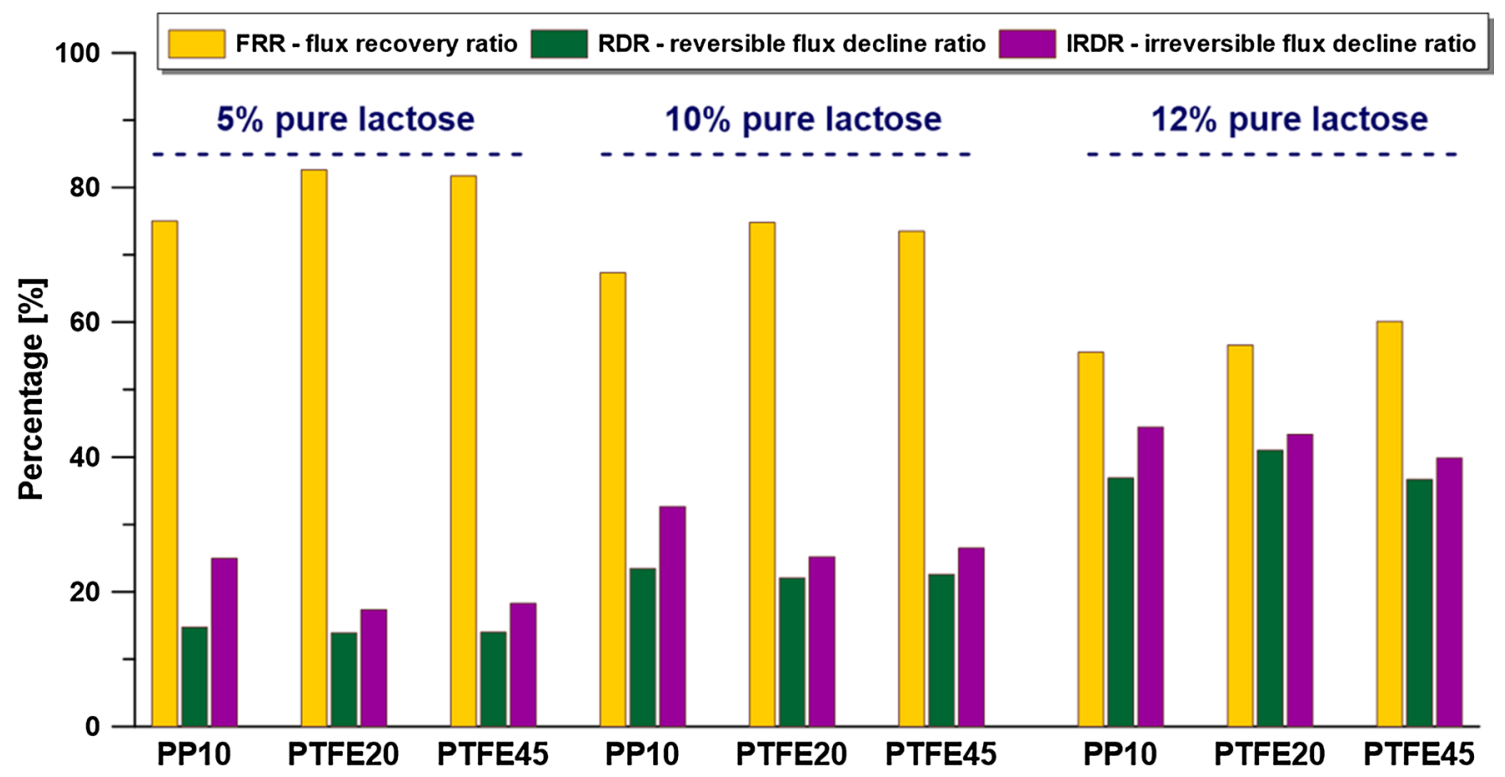

Fig. 14 Comparison of flux recovery ratio (FFR), reversible flux decline ratio (RDR), and irreversible flux decline ratio (IFDR) for polymeric membranes tested in AGMD 


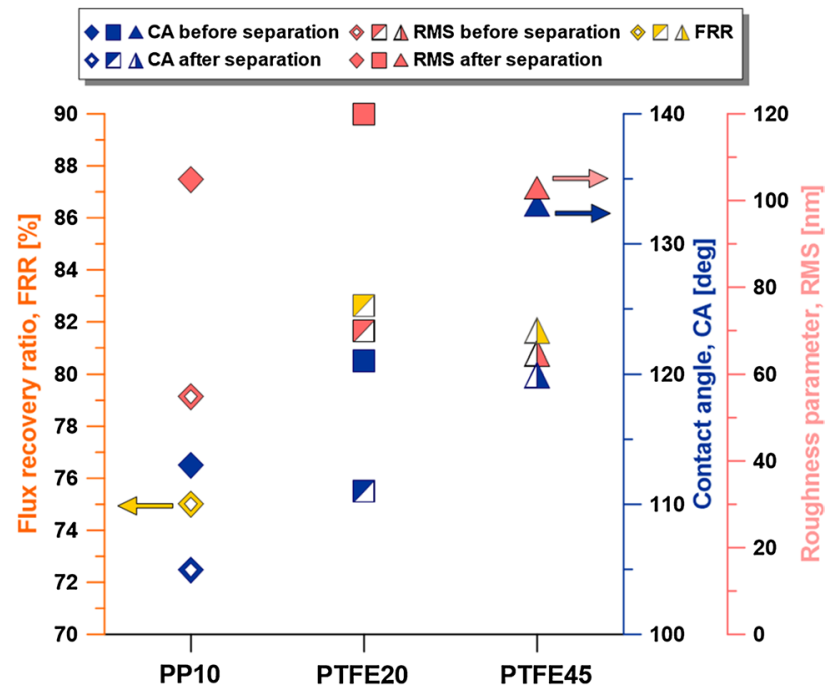

Fig. 15 Correlation between antifouling properties (FRR) and material features of the investigated polymeric membranes. Contact angle values and roughness parameters were determined before and after the separation process of $5 \%$ pure lactose model solution

\section{Conclusions}

Separation processes, like MF and AGMD, were found to be feasible to concentrate dairy products-model aqueous solutions of lactose and whey. The single component studies revealed a complex set of interactions between the material properties of the membranes, separated systems, and membrane-based separation effectiveness. The most important outcomes include the observation that the retention coefficient was independent of the type of separated system and was above $99 \%$ for AGMD with polymeric membranes. No membrane wetting was noticed in any case that was proved additionally by determination of spreading pressure parameter that was negative for all investigated membranes. In the case of the microfiltration process with ceramic membranes, a significant impact on membrane character (hydrophobicity level) has been reported. Retention coefficient of lactose with pristine hydrophilic membranes was only $80 \%$. However, as an effect of hydrophobization that parameter increased to $90 \%$. The slight impact of the type of grafting agent on the separation efficiency was observed. Better performance was found for membrane modified with a fluorinated compound. An extensive material characterization was a source of important data. For instance, measured high values of contact angle hysteresis were related to the heterogeneity of the membrane surface (high roughness parameter), which explained also the potentially greater susceptibility to fouling. Moreover, the tendency to fouling was associated with the higher contribution of polar part of the surface free energy (29\% of the polar part of SFE for PTFE45). On the other hand, the lower value of normalized flux decline was observed for PP10 membrane. In the case of PP10, the abovementioned remark was linked to the following material features: smallest contribution of polar interaction in SFE, the lowest value of roughness parameter, and HCA, especially after the separation process.

Acknowledgements This work was supported by the statutory funds of Nicolaus Copernicus University in Torun, Poland (Faculty of Chemistry, T-109 "Membranes and membrane separation processes-fundamental and applied research").

Open Access This article is distributed under the terms of the Creative Commons Attribution 4.0 International License (http://creativeco mmons.org/licenses/by/4.0/), which permits unrestricted use, distribution, and reproduction in any medium, provided you give appropriate credit to the original author(s) and the source, provide a link to the Creative Commons license, and indicate if changes were made.

\section{References}

Al-Gharabli S, Kujawski W, El-Rub ZA, Hamad EM, Kujawa J (2018) Enhancing membrane performance in removal of hazardous VOCs from water by modified fluorinated PVDF porous material. J Membr Sci 556:214-226. https://doi.org/10.1016/j.memsc i.2018.04.012

Barclay TG, Hegab HM, Michelmore A, Weeks M, Ginic-Markovic M (2018) Multidentate polyzwitterion attachment to polydopamine modified ultrafiltration membranes for dairy processing: characterization, performance and durability. Ind Eng Chem 61:356367. https://doi.org/10.1016/j.jiec.2017.12.035

Barukčić I, Božanić R, Kulozik U (2015) Influence of process temperature and microfiltration pre-treatment on flux and fouling intensity during cross-flow ultrafiltration of sweet whey using ceramic membranes. Int Dairy J 51:1-7. https://doi.org/10.1016/j.idair yj.2015.07.002

Bikerman JJ (1963) The Nature of the equilibrium spreading pressure. Kolloid Z Z Polym 191:33-35. https://doi.org/10.1007/bf014 99359

Camacho L, Dumée L, Zhang J, J-d Li, Duke M, Gomez J, Gray S (2013) Advances in membrane distillation for water desalination and purification applications. Water 5:94

Caprita R, Caprita A, Cretescu I (2014) Determination of lactose concentration in milk serum by refractometry and polarimetry. Sci Pap 47:158-161

Chen Z, Luo J, Hang X, Wan Y (2018) Physicochemical characterization of tight nanofiltration membranes for dairy wastewater treatment. J Membr Sci 547:51-63. https://doi.org/10.1016/j.memsc i.2017.10.037

Chenchaiah M, Muthukumarappan K, Metzger L (2013) Application of membrane separation technology for developing novel dairy food ingredients. J Food Process Technol 4:1000269. https://doi. org/10.4172/2157-7110.1000269

Chiu TY (2011) Effect of ageing on the microfiltration performance of ceramic membranes. Sep Purif Technol 83:106-113. https://doi. org/10.1016/j.seppur.2011.09.022

Christensen K, Andresen R, Tandskov I, Norddahl B, du Preez JH (2006) Using direct contact membrane distillation for whey protein concentration. Desalination 200:523-525. https://doi. org/10.1016/j.desal.2006.03.421

de la Fuente MA, Singh H, Hemar Y (2002) Recent advances in the characterisation of heat-induced aggregates and intermediates of 
whey proteins. Trends Food Sci Technol 13:262-274. https://doi. org/10.1016/S0924-2244(02)00133-4

Erbil HY (1997) Calculation of spreading pressure of water on cellulosic films from contact angle data. Turk J Chem 21:332-345

Erdem İ, Çiftçioğlu M, Harsa Ş (2006) Separation of whey components by using ceramic composite membranes. Desalination 189:87-91. https://doi.org/10.1016/j.desal.2005.06.016

Good RJ (1975) Spreading pressure and contact angle. J Colloid Interf Sci 52:308-313. https://doi.org/10.1016/00219797(75)90205-2

Gryta M (2008) Fouling in direct contact membrane distillation process. J Membr Sci 325:383-394. https://doi.org/10.1016/j. memsci.2008.08.001

Hausmann A, Sanciolo P, Vasiljevic T, Ponnampalam E, QuispeChavez N, Weeks M, Duke M (2011) Direct contact membrane distillation of dairy process streams. Membranes 1:48-58. https ://doi.org/10.3390/membranes 1010048

Hausmann A, Sanciolo P, Vasiljevic T, Weeks M, Schroën K, Gray S, Duke M (2013a) Fouling mechanisms of dairy streams during membrane distillation. J Membr Sci 441:102-111. https://doi. org/10.1016/j.memsci.2013.03.043

Hausmann A, Sanciolo P, Vasiljevic T, Weeks M, Schroën K, Gray S, Duke M (2013b) Fouling of dairy components on hydrophobic polytetrafluoroethylene (PTFE) membranes for membrane distillation. J Membr Sci 442:149-159. https://doi.org/10.1016/j. memsci.2013.03.057

Hausmann A, Sanciolo P, Vasiljevic T, Kulozik U, Duke M (2014) Performance assessment of membrane distillation for skim milk and whey processing. J Dairy Sci 97:56-71. https://doi. org/10.3168/jds.2013-7044

Hernández A, Calvo JI, Prádanos P, Tejerina F (1996) Pore size distributions in microporous membranes. A critical analysis of the bubble point extended method. J Membr Sci 112:1-12. https ://doi.org/10.1016/0376-7388(95)00025-9

Huppertz T (2013) Chemistry of the caseins. In: McSweeney PLH, Fox PF (eds) Advanced dairy chemistry. Volume 1A: proteins: basic aspects, 4th edn. Springer, Boston, pp 135-160. https:// doi.org/10.1007/978-1-4614-4714-6

James BJ, Jing Y, Dong Chen X (2003) Membrane fouling during filtration of milk - a microstructural study. J Food Eng 60:431437. https://doi.org/10.1016/S0260-8774(03)00066-9

Jucker BA, Harms H, Zehnder AJ (1996) Adhesion of the positively charged bacterium Stenotrophomonas (Xanthomonas) maltophilia 70401 to glass and Teflon. J Bacteriol 178:5472-5479. https://doi.org/10.1128/jb.178.18.5472-5479.1996

Jukkola A, Partanen R, Rojas OJ, Heino A (2018) Effect of heat treatment and $\mathrm{pH}$ on the efficiency of micro-diafiltration for the separation of native fat globules from cream in butter production. J Membr Sci 548:99-107. https://doi.org/10.1016/j.memsc i.2017.11.012

Karleskind D, Laye I, Mei FI, Morr CV (1995) Gelation properties of lipid reduced, and calcium reduced whey protein concentrates. J Food Sci 60:731-737. https://doi. org/10.1111/j.1365-2621.1995.tb06217.x

Kazmierski M, Corredig M (2003) Characterization of soluble aggregates from whey protein isolate. Food Hydrocolloids 17:685692. https://doi.org/10.1016/S0268-005X(03)00035-3

Knozowska K, Kujawska A, Kujawa J, Kujawski W, Bryjak M, Chrzanowska E, Kujawski JK (2017) Performance of commercial composite hydrophobic membranes applied for pervaporative reclamation of acetone, butanol, and ethanol from aqueous solutions. Binary mixtures. Sep Pur Technol 188:512-522. https:// doi.org/10.1016/j.seppur.2017.07.072

Koonaphapdeelert S, Li K (2007) Preparation and characterization of hydrophobic ceramic hollow fibre membrane. J Membr Sci 291:70-76. https://doi.org/10.1016/j.memsci.2006.12.039
Królczyk JB, Dawidziuk T, Janiszewska-Turak E, Sołowiej B (2016) Use of whey and whey preparations in the food industry-a review. Pol J Food Nutr Sci. https://doi.org/10.1515/pjfns $-2015-0052$

Kujawa J, Kujawski W (2015) Driving force and activation energy in air-gap membrane distillation process. Chem Pap 69:1438-1444. https://doi.org/10.1515/chempap-2015-0155

Kujawa J, Kujawski W (2016) Functionalization of ceramic metal oxide powders and ceramic membranes by perfluoroalkylsilanes and alkylsilanes possessing different reactive groups: physicochemical and tribological properties. ACS Appl Mater Interfaces 8:7509-7521. https://doi.org/10.1021/acsami.5b11975

Kujawa J, Guillen-Burrieza E, Arafat HA, Kurzawa M, Wolan A, Kujawski W (2015) Raw Juice concentration by osmotic membrane distillation process with hydrophobic polymeric membranes. Food Bioproc Technol 8:2146-2158. https://doi. org/10.1007/s11947-015-1570-4

Kujawa J, Al-Gharabli S, Kujawski W, Knozowska K (2017) Molecular grafting of fluorinated and non-fluorinated alkylsiloxanes on various ceramic membrane surfaces for the removal of VOCs applying vacuum membrane distillation. ACS Appl Mater Interfaces 9:6571-6590. https://doi.org/10.1021/acsami.6b14835

Kujawska A, Kujawski JK, Bryjak M, Cichosz M, Kujawski W (2016) Removal of volatile organic compounds from aqueous solutions applying thermally driven membrane processes. 2 Air gap membrane distillation. J Membr Sci 499:245-256. https://doi. org/10.1016/j.memsci.2015.10.047

Kujawski W, Adamczak P, Narebska A (1989) A fully automated system for the determination of pore size distribution in microfiltration and ultrafiltration membranes. Sep Purif Technol 24:495-506. https://doi.org/10.1080/01496398908049787

Laqbaqbi M, Sanmartino J, Khayet M, García-Payo C, Chaouch M (2017) Fouling in membrane distillation osmotic distillation and osmotic membrane distillation. Appl Sci 7:334

Law K-Y, Zhao H (2016) Determination of solid surface tension by contact angle. In: Law K-Y, Zhao H (eds) Surface wetting: characterization, contact angle, and fundamentals. Springer, Cham, pp 135-148. https://doi.org/10.1007/978-3-319-25214-8_7

Moejes SN, van Boxtel AJB (2017) Energy saving potential of emerging technologies in milk powder production. Trends Food Sci Technol 60:31-42. https://doi.org/10.1016/j.tifs.2016.10.023

Moro A, Gatti C, Delorenzi N (2001) Hydrophobicity of whey protein concentrates measured by fluorescence quenching and its relation with surface functional properties. J Agric Food Chem 49:47844789. https://doi.org/10.1021/jf001132e

Mourouzidis-Mourouzis SA, Karabelas AJ (2006) Whey protein fouling of microfiltration ceramic membranes-pressure effects. J Membr Sci 282:124-132. https://doi.org/10.1016/j.memsc i.2006.05.012

Mourouzidis-Mourouzis SA, Karabelas AJ (2008) Whey protein fouling of large pore-size ceramic microfiltration membranes at small cross-flow velocity. J Membr Sci 323:17-27. https://doi. org/10.1016/j.memsci.2008.05.053

Nath K, Dave HK, Patel TM (2018) Revisiting the recent applications of nanofiltration in food processing industries: progress and prognosis. Trends Food Sci Technol 73:12-24. https://doi. org/10.1016/j.tifs.2018.01.001

Plisko TV et al (2018) Fabrication and characterization of polyamidefullerenol thin film nanocomposite hollow fiber membranes with enhanced antifouling performance. J Membr Sci 551:20-36. https ://doi.org/10.1016/j.memsci.2018.01.015

Pruksasri S (2015) Dairy stream lactose fractionation/concentration using polymeric ultrafiltration membrane. In: Hu K, Dickson JM (eds) Membrane processing for dairy ingredient separation. Wiley, Chichester, pp 35-66. https://doi.org/10.1002/9781118590331 
Qtaishat MR, Banat F (2013) Desalination by solar powered membrane distillation systems. Desalination 308:186-197. https://doi. org/10.1016/j.desal.2012.01.021

Rezaei H, Ashtiani FZ, Fouladitajar A (2014) Fouling behavior and performance of microfiltration membranes for whey treatment in steady and unsteady-state conditions. Braz J Chem Eng 31:503-518

Safarpour M, Vatanpour V, Khataee A (2016) Preparation and characterization of graphene oxide/ $\mathrm{TiO}_{2}$ blended PES nanofiltration membrane with improved antifouling and separation performance. Desalination 393:65-78. https://doi.org/10.1016/j.desal .2015 .07 .003

Shafi HZ, Matin A, Akhtar S, Gleason KK, Zubair SM, Khan Z (2017) Organic fouling in surface modified reverse osmosis membranes: Filtration studies and subsequent morphological and compositional characterization. J Membr Sci 527:152-163. https://doi. org/10.1016/j.memsci.2017.01.017

Soodam K, Guinee TP (2018) The case for milk protein standardisation using membrane filtration for improving cheese consistency and quality. Int J Dairy Technol 71:277-291. https://doi. org/10.1111/1471-0307.12502

Steinhauer T, Marx M, Bogendörfer K, Kulozik U (2015) Membrane fouling during ultra- and microfiltration of whey and whey proteins at different environmental conditions: The role of aggregated whey proteins as fouling initiators. J Membr Sci 489:20-27. https ://doi.org/10.1016/j.memsci.2015.04.002

Szczerbińska J, Kujawski W, Arszyńska JM, Kujawa J (2017) Assessment of air-gap membrane distillation with hydrophobic porous membranes utilized for damaged paintings humidification. J Membr Sci 538:1-8. https://doi.org/10.1016/j.memsc i.2017.05.048

Tomaszewska M, Białończyk L (2013) Influence of proteins content in the feed on the course of membrane distillation. Desalin Water Treat 51:2362-2367. https://doi.org/10.1080/19443 994.2012.728052

Yorgun MS, Balcioglu IA, Saygin O (2008) Performance comparison of ultrafiltration, nanofiltration and reverse osmosis on whey treatment. Desalination 229:204-216. https://doi.org/10.1016/j.desal 2007.09.008

Zaragoza G, Ruiz-Aguirre A, Guillén-Burrieza E (2014) Efficiency in the use of solar thermal energy of small membrane desalination systems for decentralized water production. Appl Energy 130:491-499. https://doi.org/10.1016/j.apenergy.2014.02.024

Zhao X, Su Y, Li Y, Zhang R, Zhao J, Jiang Z (2014) Engineering amphiphilic membrane surfaces based on PEO and PDMS segments for improved antifouling performances. J Membr Sci 450:111-123. https://doi.org/10.1016/j.memsci.2013.08.044 